\title{
Buku Panduan Penggunaan Aplikasi PhET untuk SMP
}

Dr. Septi Budi Sartika, M.Pd. Eni Setiyoningrum, S.Pd.

\section{UmsidaPress}




\section{BUKU PANDUAN \\ PENGGUNAAN APLIKASI PHET UNTUK SMP}

Oleh

Dr. Septi Budi Sartika, M.Pd.

Eni Setiyoningrum, S.Pd.

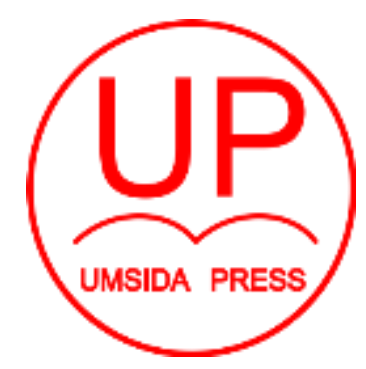

Diterbitkan oleh

UMSIDA PRESS

Jl. Mojopahit 666 B Sidoarjo

ISBN: 978-623-6833-03-2

Copyright@ 2020.

Didik Hariyanto dan Ferry Adhi Dharma

All rights reserved 


\section{BUKU PANDUAN}

\section{PENGGUNAAN APLIKASI PHET UNTUK SMP}

\section{Penulis:}

Dr. Septi Budi Sartika, M.Pd.

Eni Setiyoningrum, S.Pd.

\section{ISBN :}

978-623-6833-03-2

\section{Editor:}

Dr. Nur Efendi, M.Pd.

Noly Shofiyah, M.Pd., M.Sc.

\section{Copy Editor:}

Mahardika Darmawan Kusuma Wardana, M.Pd.

\section{Design Sampul dan Tata Letak:}

Mochammad Nashrullah, S.Pd.

Penerbit:

UMSIDA Press

Anggota IKAPI No. 218/Anggota Luar Biasa/JTI/2019

Anggota APPTI No. 0020181092017

Redaksi

Universitas Muhammadiyah Sidoarjo

Jl. Mojopahit No 666B

Sidoarjo, Jawa Timur

Cetakan Pertama, Oktober 2020

CHak Cipta dilindungi undang undang

Dilarang memperbanyak karya tulis ini dengan sengaja, tanpa ijin tertulis dari penerbit. 


\section{KATA PENGANTAR}

Puji syukur kehadirat Alloh SWT, atas segala karunia dan petunjuk-Nya lah buku Panduan Penggunaan Aplikasi PhET telah diselesaikan tanpa halangan suatu apapun. Penulis berterima kasih kepada:

1. Dr. Hidayatulloh, M.Si., Rektor UMSIDA yang selalu memberikan dukungan moril dalam memfasilitasi dosen membuat karya ilmiah.

2. Dr. Sigit Hermawan, SE., M.Si., CiQaR., Direktur Direktorat Riset dan Pengabdian kepada Masyarakat UMSIDA yang telah mendukung program kegiatan abdimas dosen di lingkungan UMSIDA sekaligus penghargaan yang terbesar kepada kami sebagai Tim Pengabdi Terbaik Tahun 2020.

3. Dr. Akhtim Wahyuni, M.Ag., Dekan Fakultas Psikologi dan Ilmu Pendidikan yang telah memberikan dukungan dalam pengembangan karya ilmiah dosen.

4. Noly Shofiyah, M.Pd., M.Sc., Kaprodi Pendidikan IPA Fakultas Psikologi dan Ilmu Pendidikan Universitas Muhammadiyah Sidoarjo.

5. Rekan-rekan sejawat dan mahasiswa prodi Pendidikan IPA yang turut serta dalam penyempurnaan buku panduan ini.

6. Pihak-pihak yang tidak bisa kami sebutkan satu-persatu yang turut membantu dalam penyelesaian buku panduan ini.

Besar harapan penulis untuk kritik dan saran bagi para pembaca demi kesempurnaan buku panduan ini.

Tim Penulis, 


\section{DAFTAR ISI}

Halaman Sampul

i

Identitas Buku

ii

Kata Pengantar

iii

Daftar Isi

iv

BAB I

CARA MENDOWNLOAD PHET

DAN JAVA

BAB II

CARA MENGINSTAL PHET DAN

JAVA

BAB III

CARA MENGOPERASIKAN PHET

BAB IV

CONTOH PENGGUNAAN PHET

PADA PRAKTIKUM IPA SMP

$\mathrm{BAB} \mathrm{V}$

PEMETAAN MATA PRAKTIKUM

MAYA PADA MAPEL IPA DAN

MATEMATIKA SMP

Daftar Pustaka 


\section{BAB I}

\section{CARA MENDOWNLOAD PHET DAN JAVA}

\section{A. Cara Mendownload PhET Interactive Simulation}

Agar dapat menggunakan PhET Interactive Simulation secara offline maka terlebih dahulu harus memiliki aplikasi PhET Interactive Simulation. adapun langkah-langkah untuk mendownload PhET Interactive Simulation adalah sebagai berikut :

1. Untuk mendapatkan aplikasi PhET Interactive Simulation dapat di dapatkan dengan mengakses melalui google.

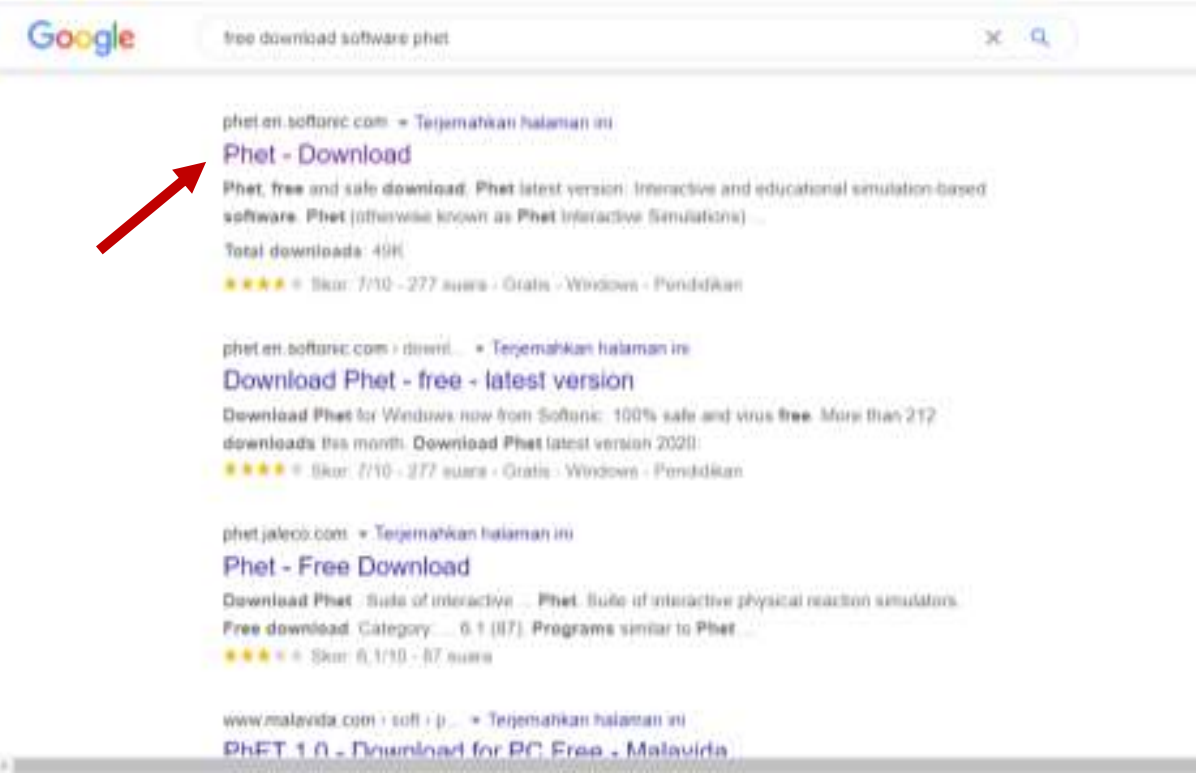

Klik "PhET Download” lalu ikuti tahap selanjutnya.

2. Setelah klik "PhET Download" maka akan terdapat tampilan berikut,

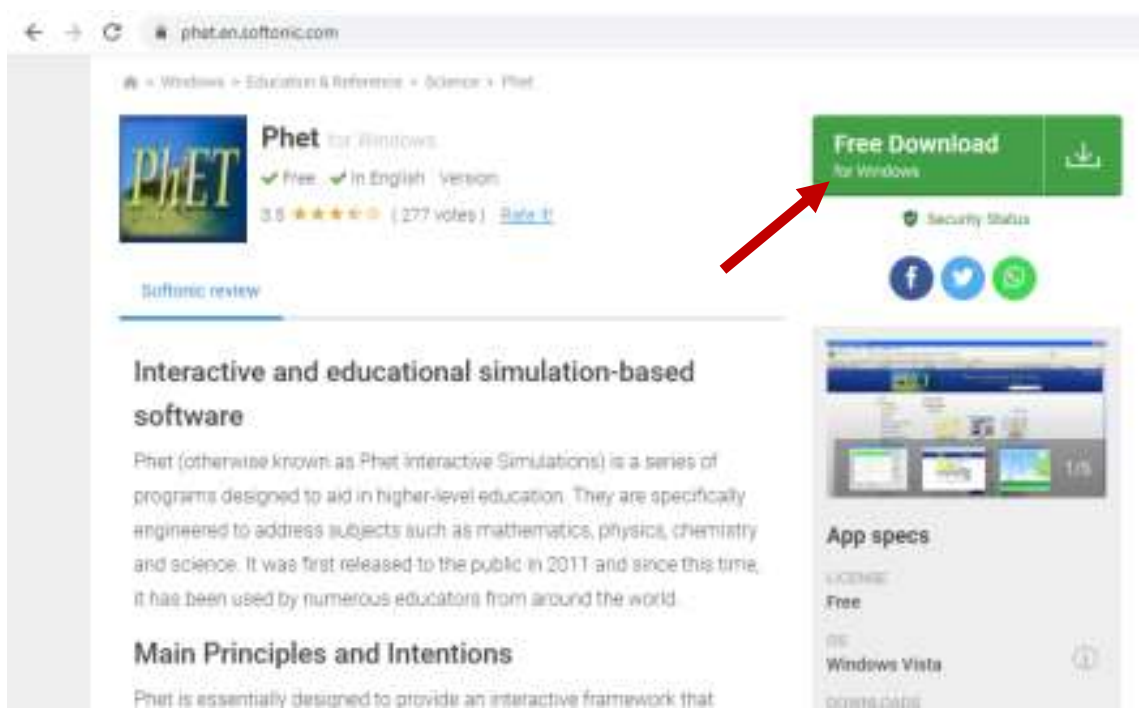

Klik "Free Download" lalu ikuti tahap selanjutnya. 
3. Setelah klik "Free Download" maka akan terdapat tampilan berikut,

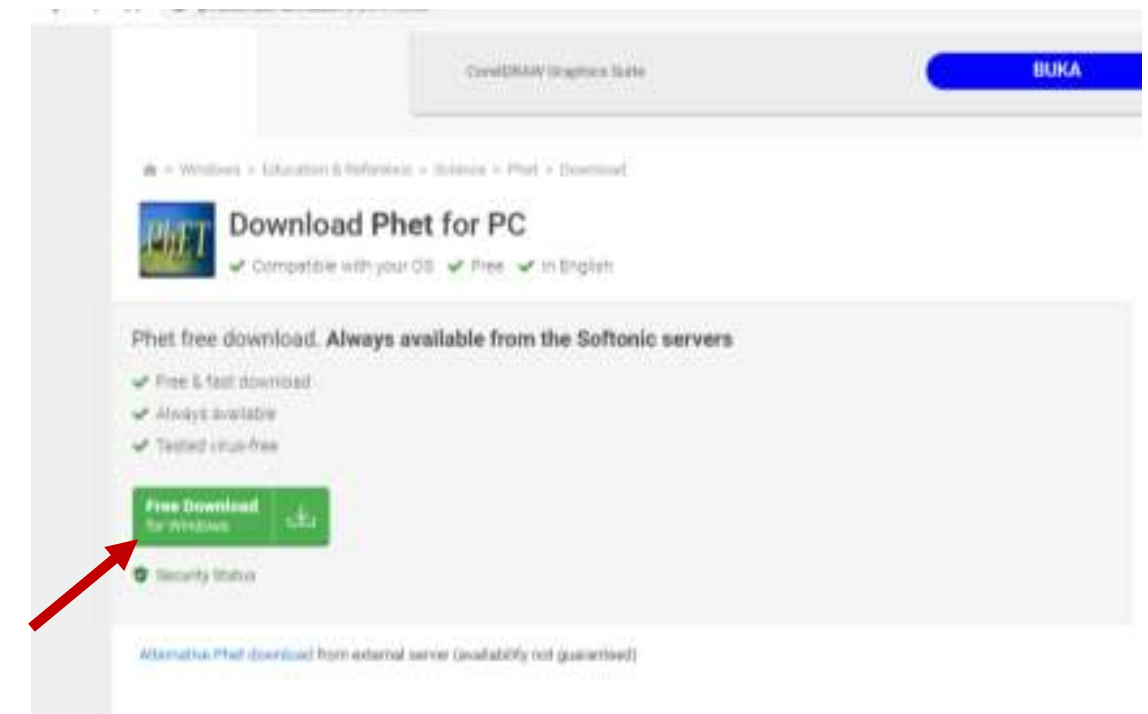

Pada tahap ini akan muncul "Free Download" seperti tahap sebelumnya, maka klik kembali "Free Download" setelah itu aplikasi PhET Interactive Simulation dalam proses Download dan tunggulah hingga proses Download terselesaikan.

\section{B. Cara Mendownload Java}

Penggunaan aplikasi PhET Interactive Simulation diiringi dengan tersedianya aplikasi $J a v a$, karena terdapat beberapa topik yang dapat digunakan mengguakan bantuan aplikasi Java. Sebelum menggunakan aplikasi Java maka terlebih dahulu mendownload aplikasi Java, adapun langkah-langkah mendownload aplikasi Java adalah sebagi berikut :

1. Untuk mendapatkan aplikasi Java dapat di dapatkan dengan mengakses melalui google.

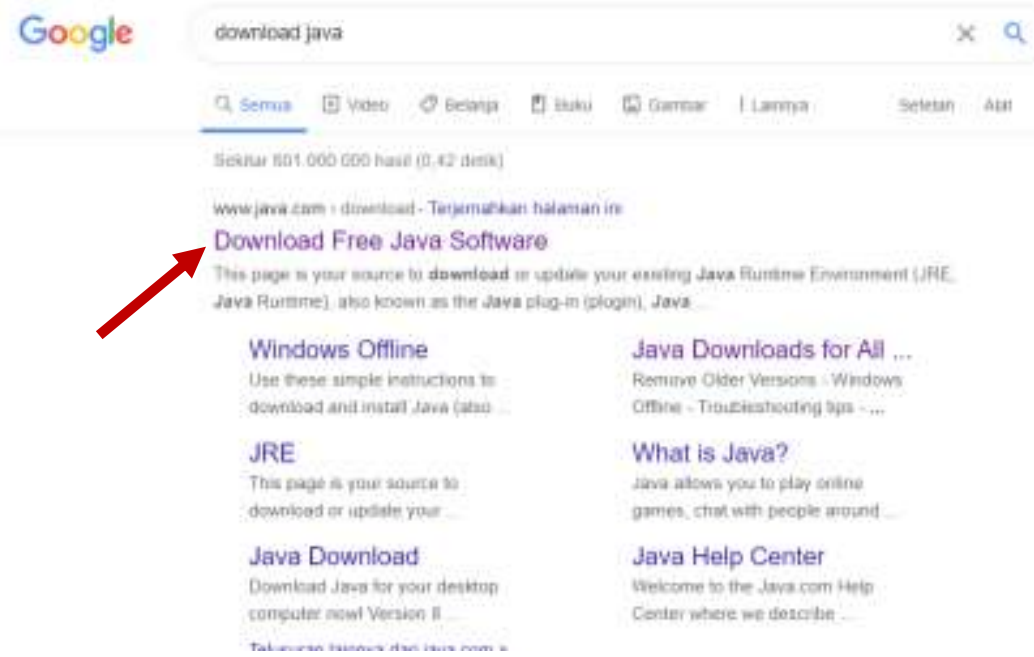

Klik "Download Free Java Software” lalu ikuti tahap selanjutnya.

2. Setelah klik "Download Free Java Software” maka akan terdapat tampilan berikut, 


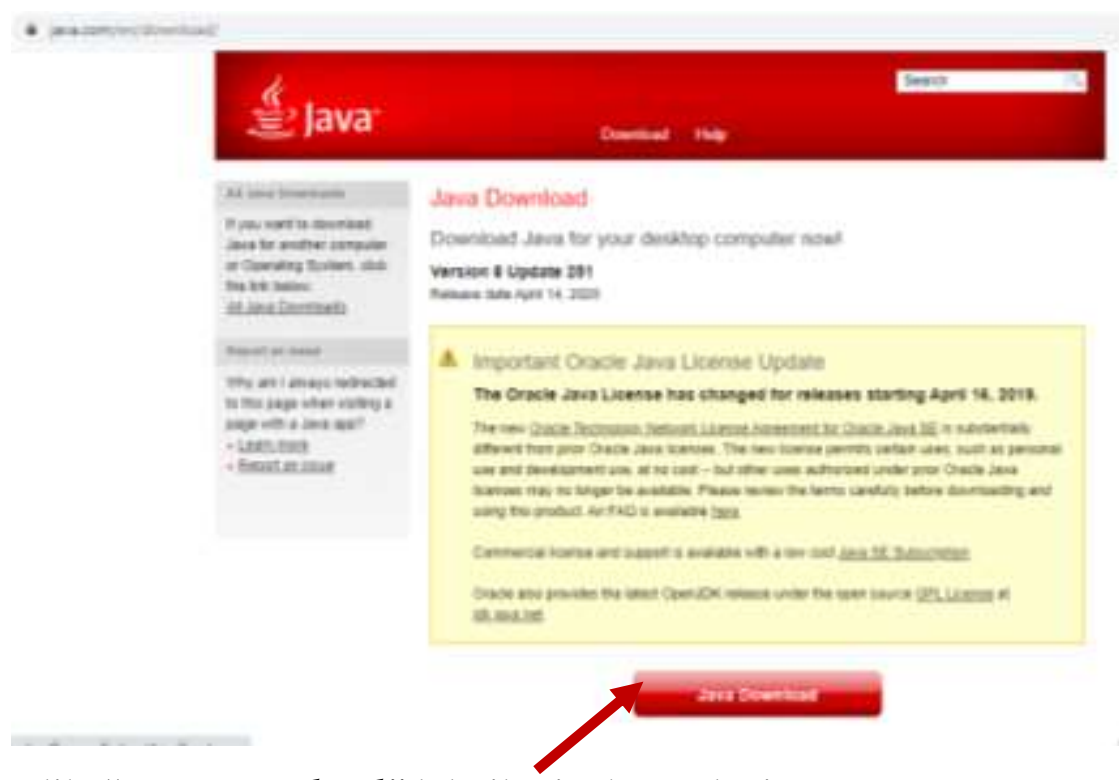

Klik “Java Download” lalu ikuti tahap selanjutnya.

3. Setelah klik "Java Download” maka akan terdapat tampilan berikut,

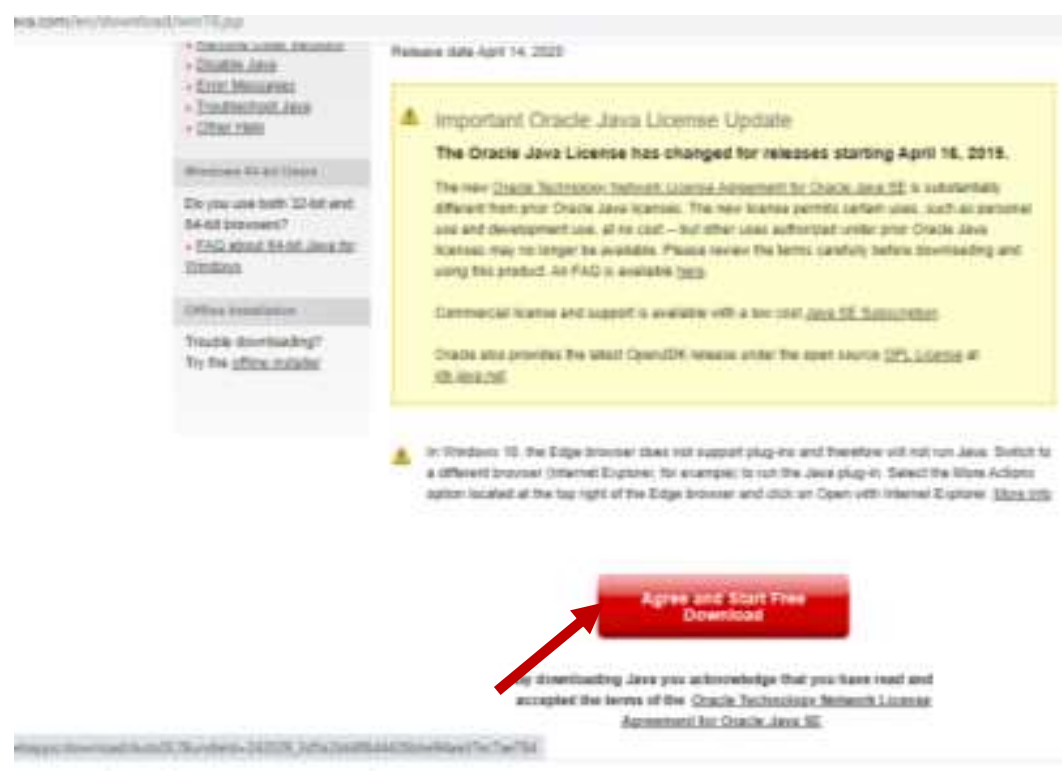

Pada tahap ini akan muncul "Agree and Start Free Download”, klik pilihan tersebut setelah itu aplikasi Java dalam proses Download dan tunggulah hingga proses Download terselesaikan. 


\section{BAB II}

\section{CARA MENGINSTALL PHET DAN JAVA}

\section{A. Cara Menginstall PhET Interactive Simulation}

Setelah aplikasi PhET Interactive Simulation berhasil diunduh, agar dapat digunakan maka perlu diinstal atau dipasang terlebih dahulu. Adapun langkah-langkah menginstall atau memasang aplikasi PhET Interactive Simulation adalah sebagai berikut :

1. Bukalah file Soft Ware PhET Interactive Simulation yang telah terunduh pada leptop atau komputer

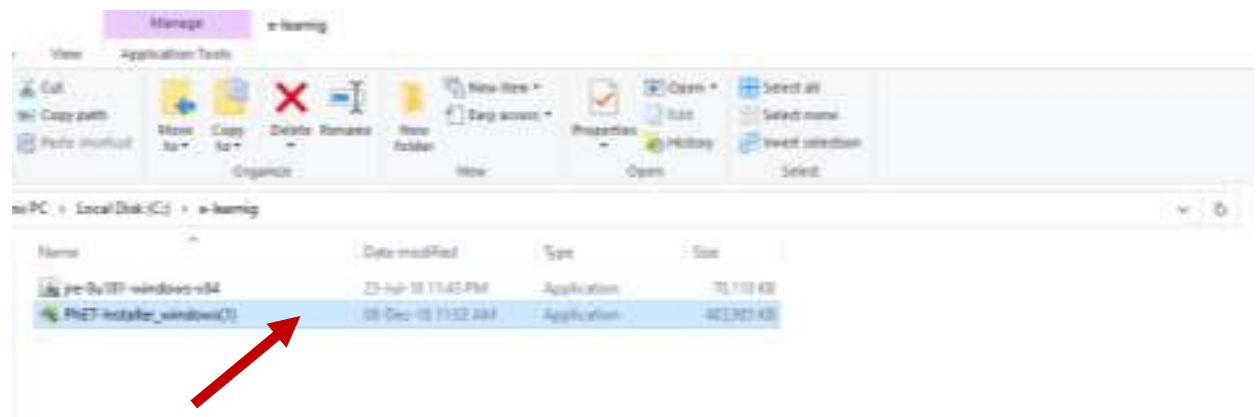

Klik aplikasi PhET Interactive Simulation, lalu ikuti tahap selanjutnya.

2. Setelah aplikasi PhET Interactive Simulation terbuka maka akan terdapat tampilan berikut,

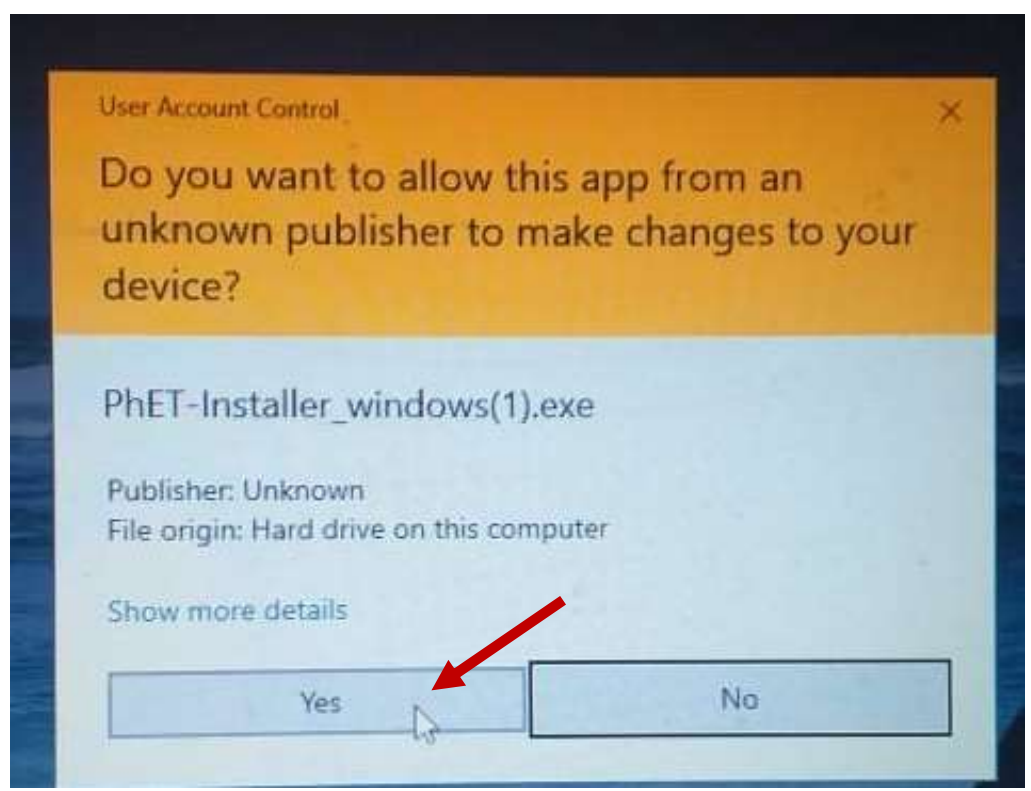

Klik "Yes" lalu ikuti tahap selanjutnya

3. Setelah memilih opsion "Yes" maka akan terdapat tampilan berikut, 


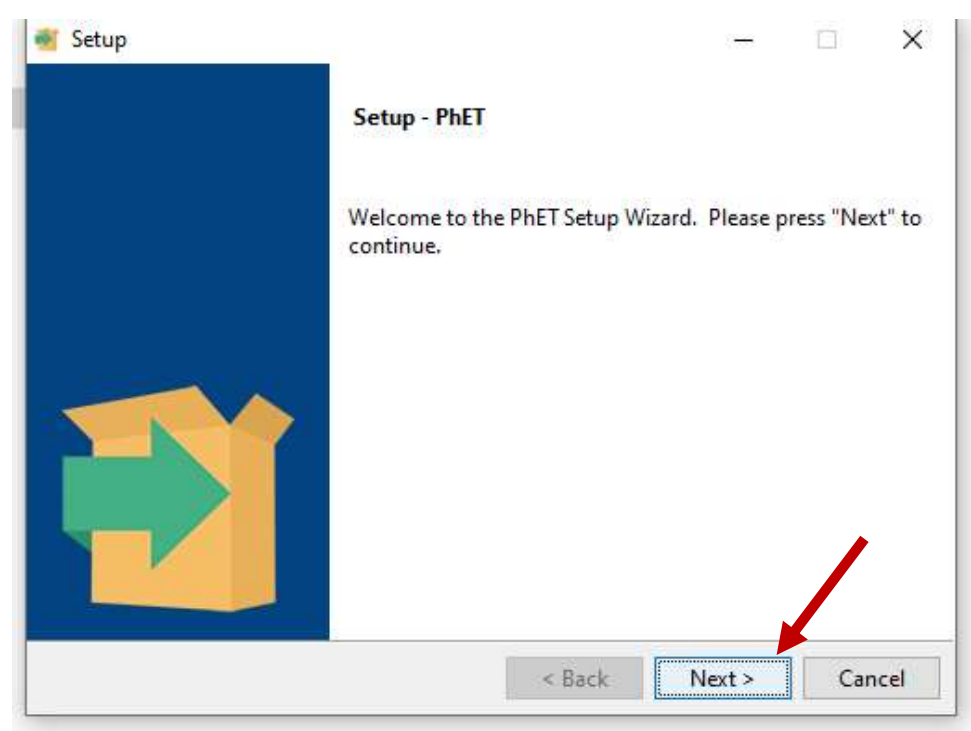

Klik "Next” lalu ikuti tahap selanjutnya.

4. Setelah memilih "Next" maka terdapat tampilan berikut,

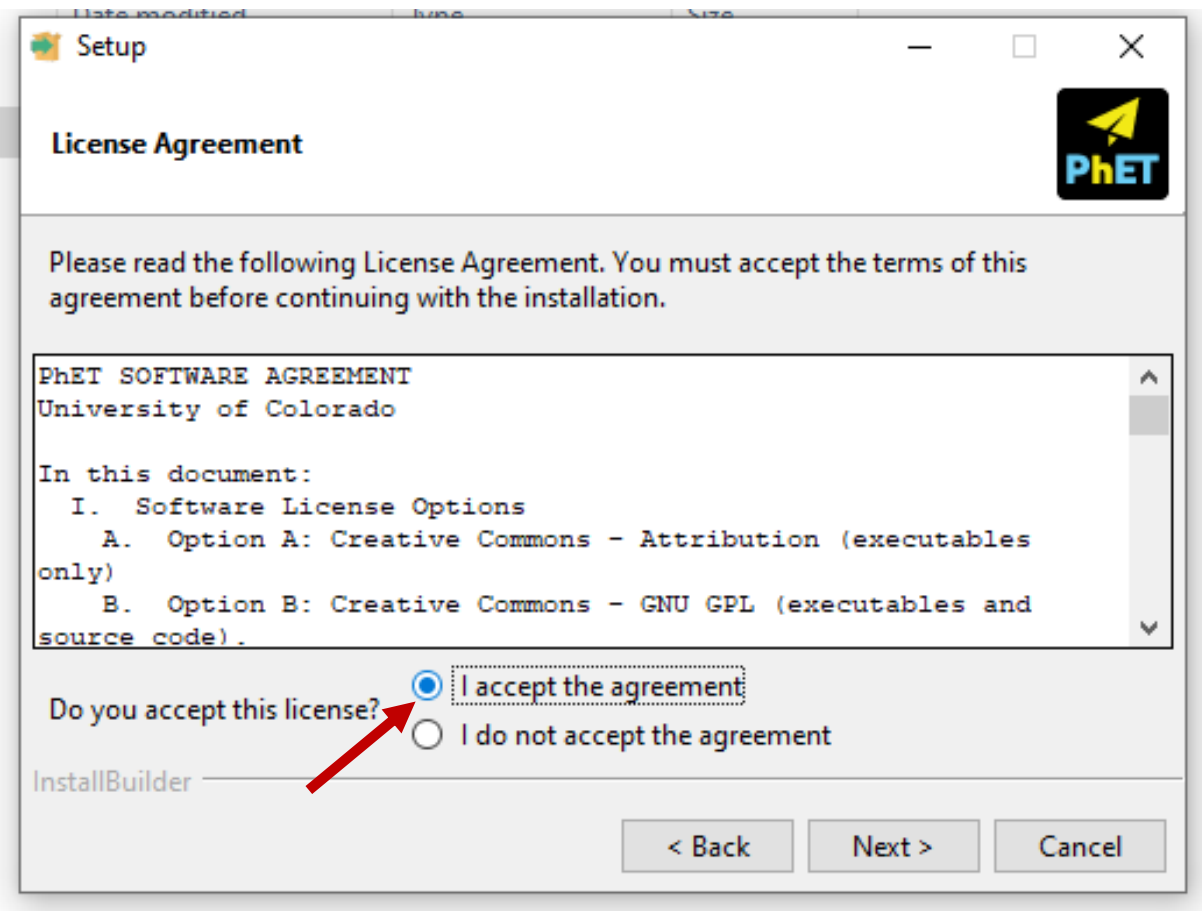

Klik "I accept the agreement" dan pastikan terdapat tanda pada opsion tersebut

5. Setelah memberi tanda pada "I accept the agreement" maka akan terdapat tampilan berikut, 


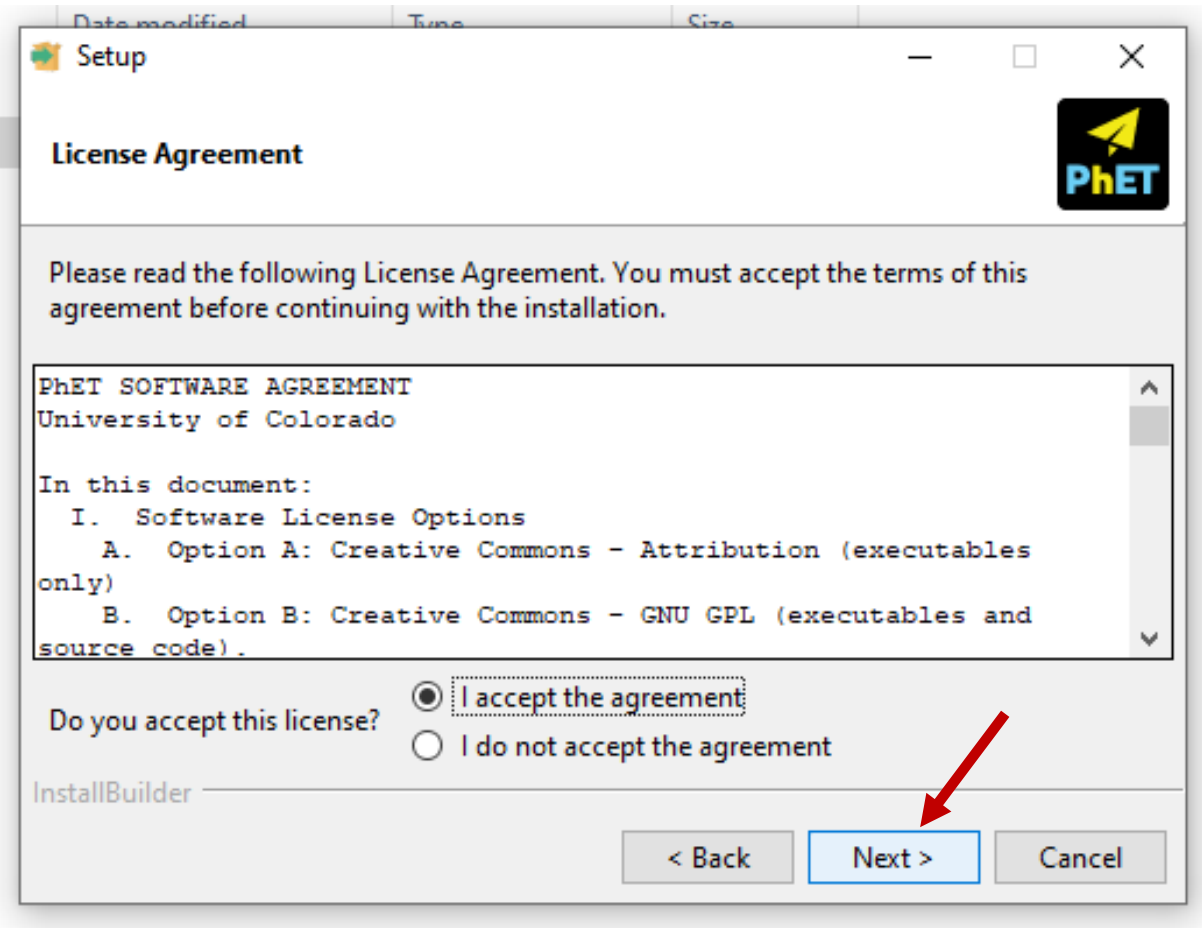

Klik "Next” lalu ikuti tahap selanjutnya.

6. Setelah memilih "Next" maka terdapat tampilan berikut,

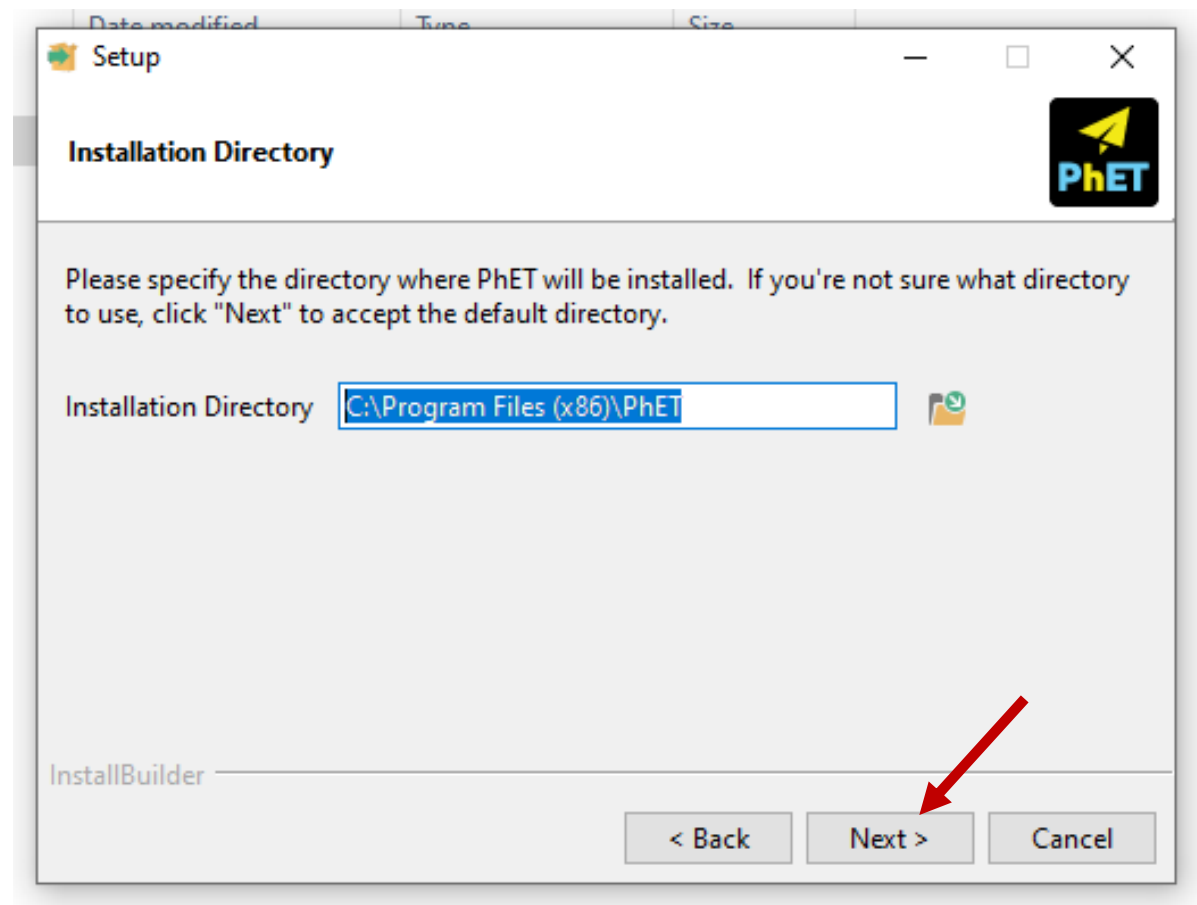

Klik "Next" lalu ikuti tahap selanjutnya.

7. Setelah memilih "Next" maka terdapat tampilan berikut, 


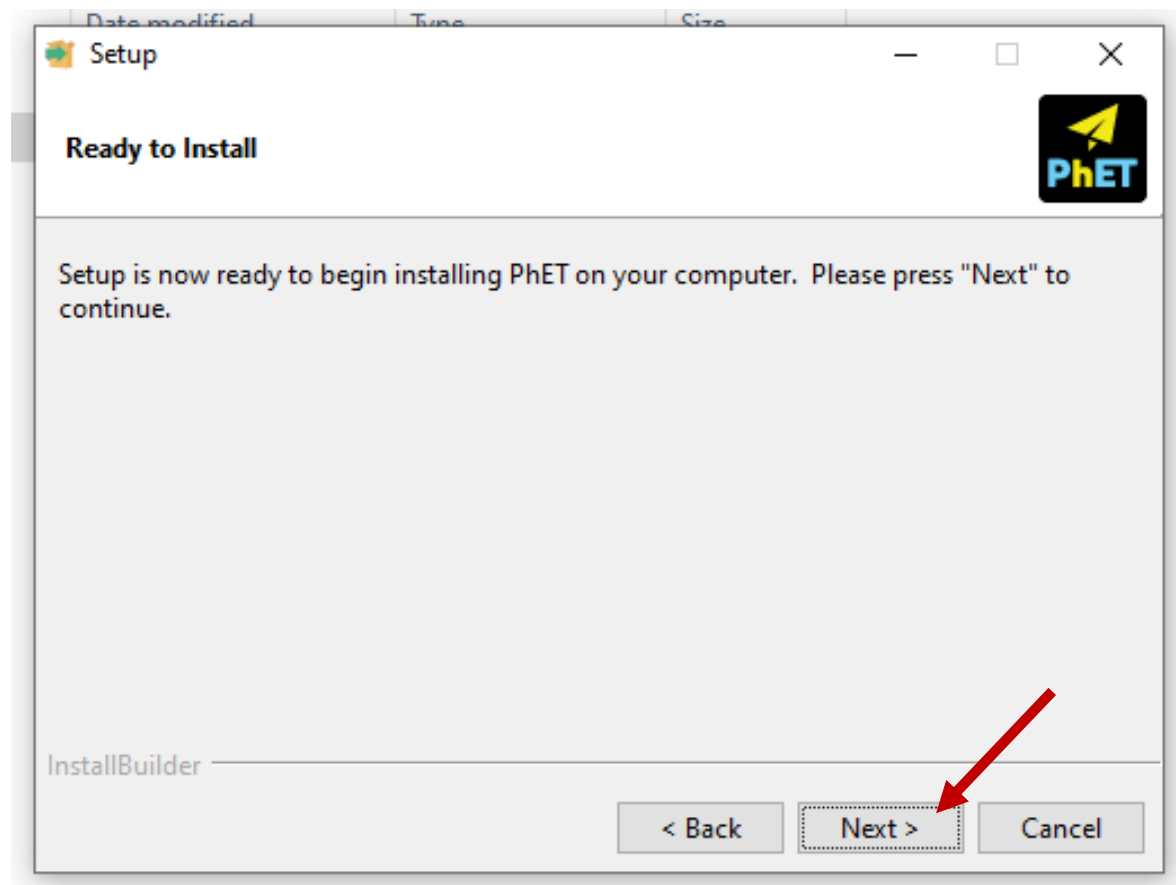

Klik "Next" lalu ikuti tahap selanjutnya.

8. Setelah memilih "Next" maka terdapat tampilan berikut,

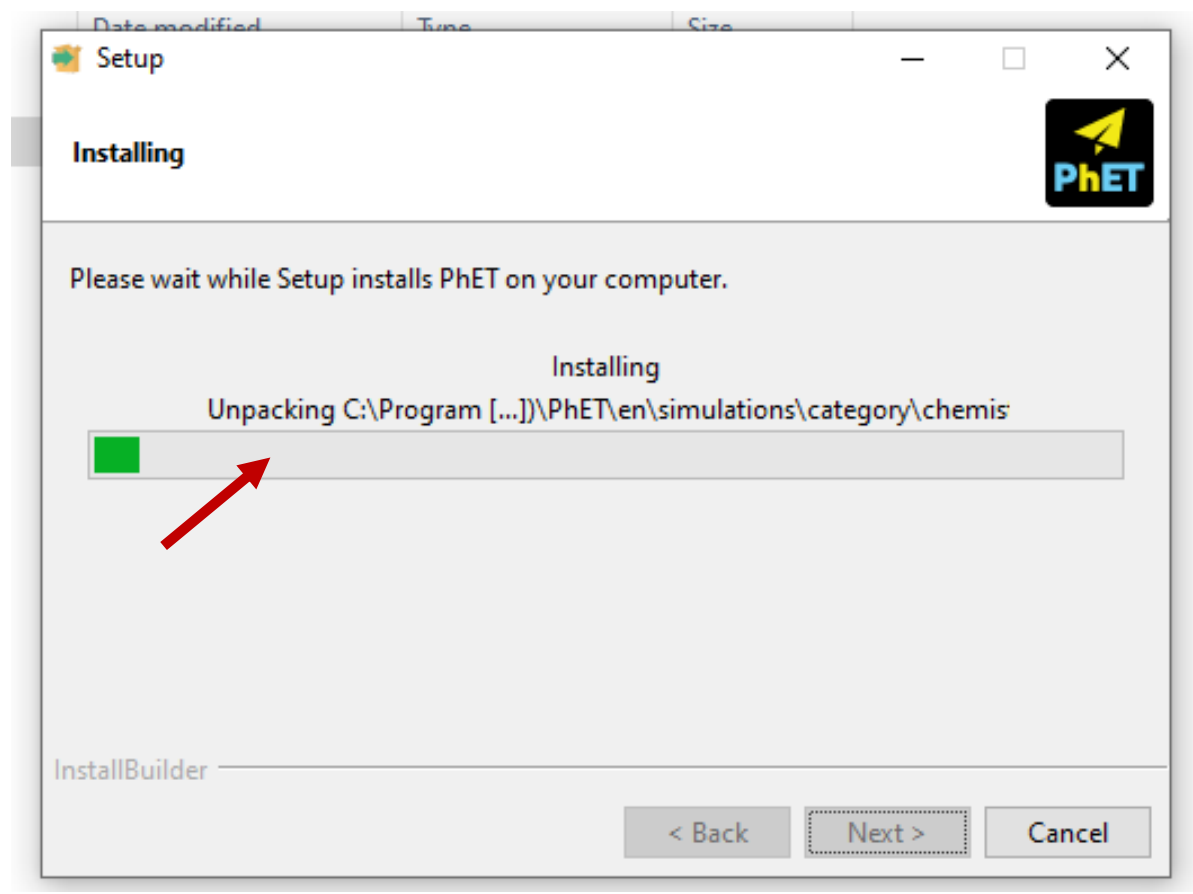

Pada tahap ini merupakan tahap terakhir dalam menginstall atau memasang aplikasi PhET Interactive Simulation. Tunggulah hingga proses pemasangan selesai ditandai dengan terpenuhinya tanda hijau pada proses tersebut. Jika pemasangan telah selesai maka aplikasi PhET Interactive Simulation siap untuk digunakan. 


\section{B. Cara Menginstall Java}

Jika aplikasi Java telah terdownload maka perlu untuk diinstall atau dipasang terlebih dahulu pada leptop atau computer sebagai pendamping penggunaan aplikasi PhET Interactive Simulation. Adapun langkah-langkah untuk menginstall atau memasang aplikasi Java adalah sebagai berikut :

1. Bukalah file Soft Ware Java yang telah terunduh pada leptop atau komputer

\begin{tabular}{|c|c|c|c|}
\hline Name & Date modified & Type & Size \\
\hline jre-8u181-windows-x64 & 23-Jul-18 11:43 PM & Application & $70,110 \mathrm{~KB}$ \\
\hline S PhET-Installer_windor & 08-Dec-18 11:53 AM & Application & $483,985 \mathrm{~KB}$ \\
\hline
\end{tabular}

Klik aplikasi Java, lalu ikuti tahap selanjutnya.

2. Setelah aplikasi Java terbuka maka akan terdapat tampilan berikut,

\section{Do you want to allow this app to make} changes to your device?

Java SE Runtime Environment 8 Update 181

Verified publisher: Oracle America, Inc.

File origin: Hard drive on this computer

Show more details

$\pi$ Yes $\quad$ No

Klik "Yes" lalu ikuti tahap selanjutnya

3. Setelah memilih opsion "Yes" maka akan terdapat tampilan berikut,

Java Setup - Welcome
Java provides access to a world of amazing content. From business solutions to helpful utilities and
entertainment, Java makes your Internet experience come to life.
Note: No personal information is gathered as part of our install process. Click here for more information on
what we do collect.
Click Install to accept the license agreement and install Java now.


Klik "Install” lalu ikuti tahap selanjutnya

4. Setelah memilih "Install" maka terdapat tampilan berikut,

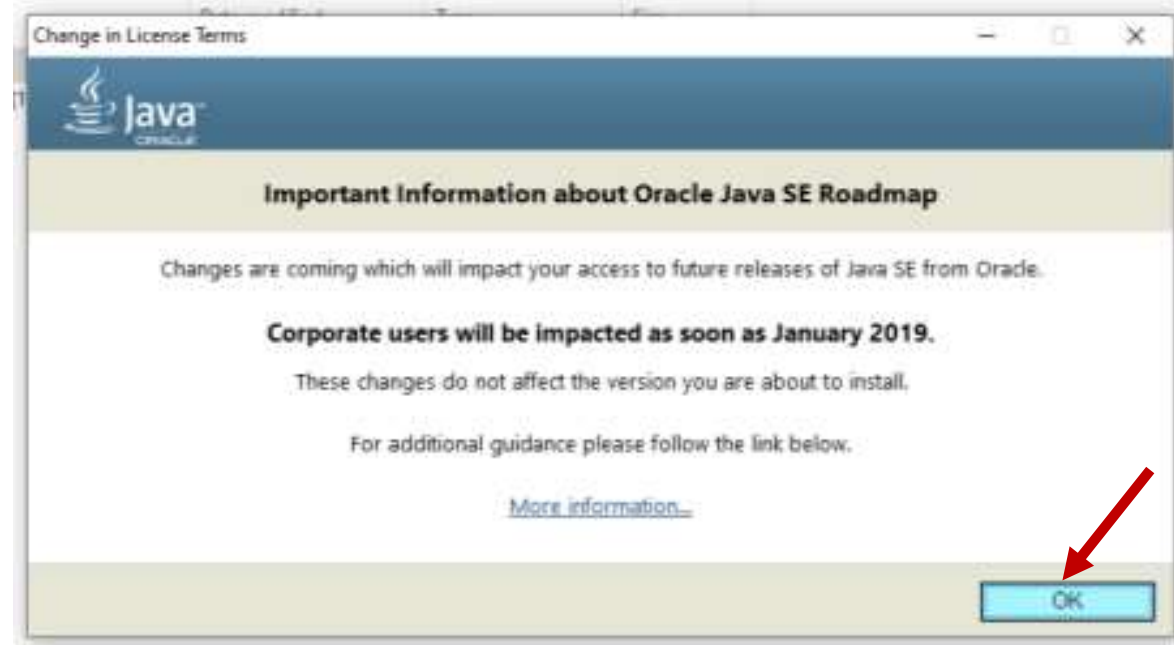

Klik “ $O K$ ” lalu ikuti tahap selanjutnya

5. Setelah memilih "OK” maka terdapat tampilan berikut,

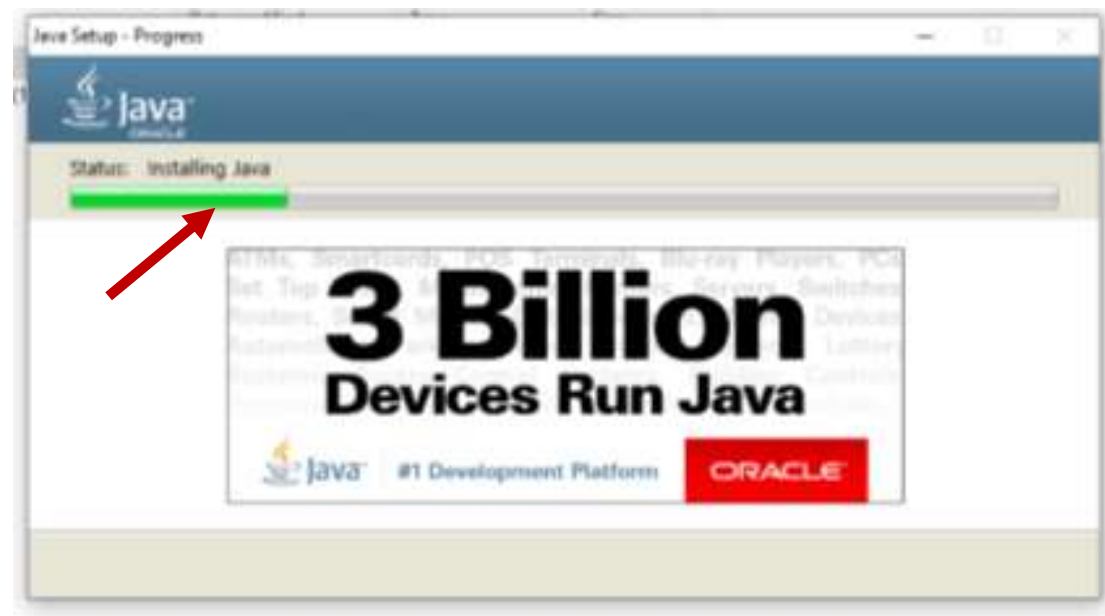

Pada tahap ini adalah proses pemasangan aplikasi Java pada leptop atau komputer. Tunggulah hingga warna hijau terpenuhi. Setelah terpenuhi maka aplikasi Java telah terpasang dan siap digunakan. 


\section{BAB III \\ CARA MENGOPERASIKAN PHET}

Setelah aplikasi PhET Interactive Simulation telah terpasang pada leptop atau komputer, maka aplikasi tersebut dapat digunakan secara offline. Pada aplikasi PhET Interactive Simulation komponen didalamnya dominan dengan Bahasa Inggris, karena aplikasi ini merupakan aplikasi yang berasal dari University of Colorado, namun dapat pula diubah dalam Bahasa lain untuk mengetahui judul atau topik simulasi. Aplikasi ini berisi simulasi pembelajaran fisika, kimia, biologi, kebumian dan matematika.

Adapun langkah-langjah untuk menggunakan aplikasi PhET Interactive Simulation adalah sebagai berikut :

1. Buka aplikasi PhET Interactive Simulation yang telah terpasang pada leptop atau komputer

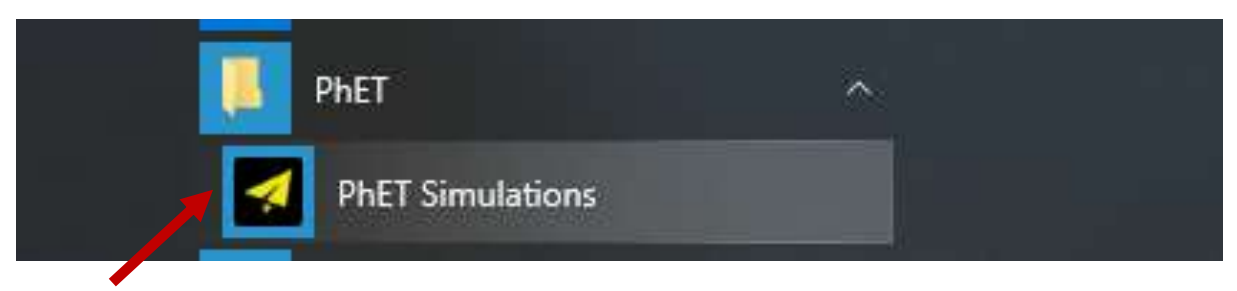

Klik aplikasi PhET Interactive Simulation lalu ikuti tahap selanjutnya

2. Setelah membuka aplikasi PhET Interactive Simulation maka akan terlihat tampilan seperti berikut,

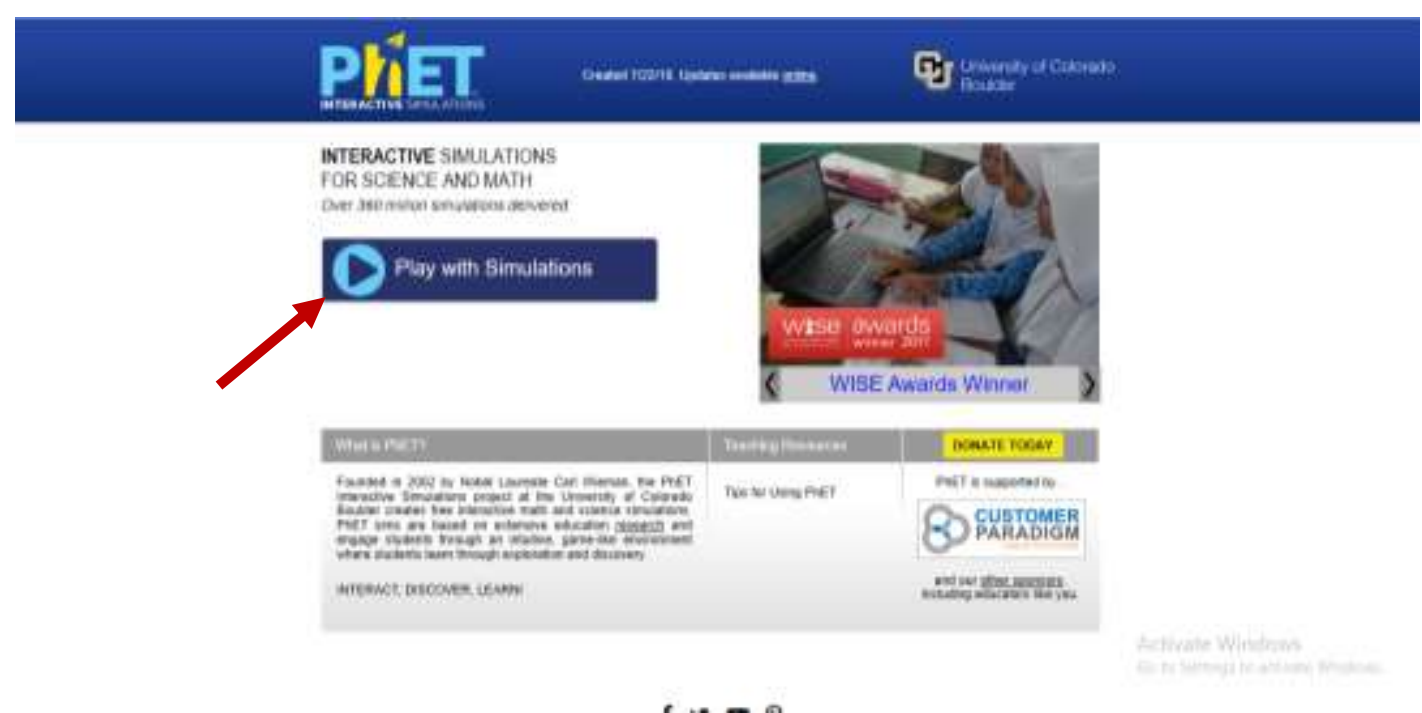

Jika aplikasi PhET Interactive Simulation telah terbuka maka pilih "Play with Simulation"

3. Setelah memulai penggunaan aplikasi PhET Interactive Simulation maka akan terlihat tampilan dari isi aolikasi tersebut 


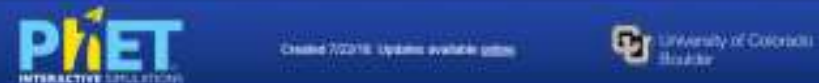

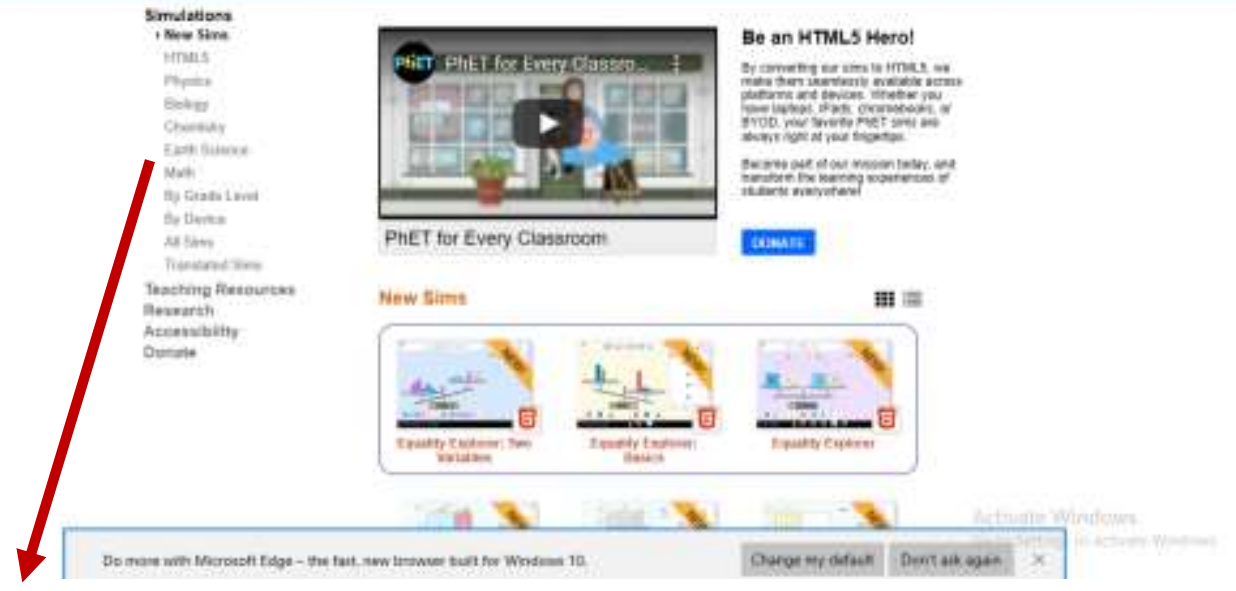

Physics

Biology

Chemistry

Earth Science

Math

Pada tampilan awal aplikasi PhET Interactive Simulation, pada bagian yang ditunjuk terdapat pilihan mata pelajaran yang disediakan, yaitu fisika, biologi, kimia, kebumian dan matematika. Pada masing-masing pelajaran tersedia topik pembelajaran simulasi. Pengguna bebas memilih sesuai deengan kebutuhan.

4. Sebagai contoh akan dipilih salah satu pelajaran sebagai berikut,

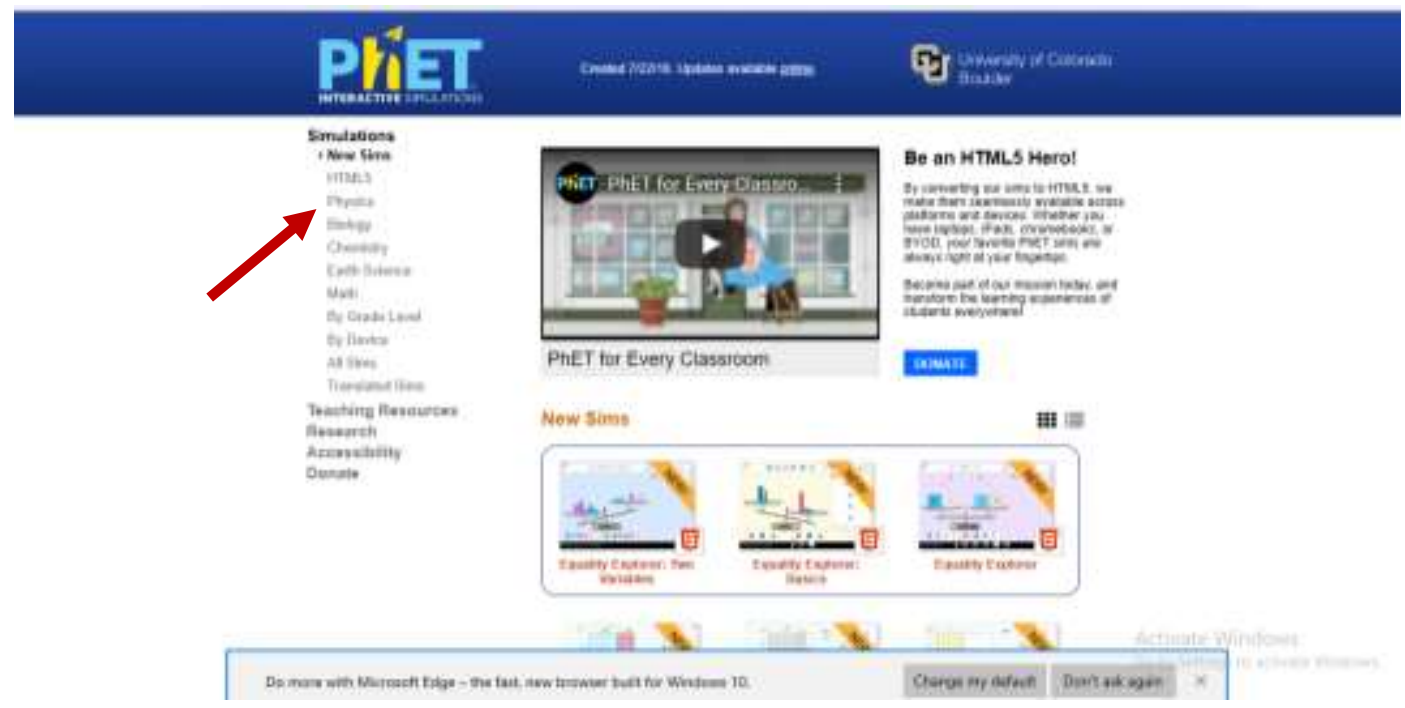

Misalnya pada pelajaran fisika, maka pada tampilan ini silahkan klik "Physics"

5. Setelah memilih pelajaran yang diinginkan pada contoh ini yaitu "Physics" maka akan terdapat tampilan sebagai berikut, 


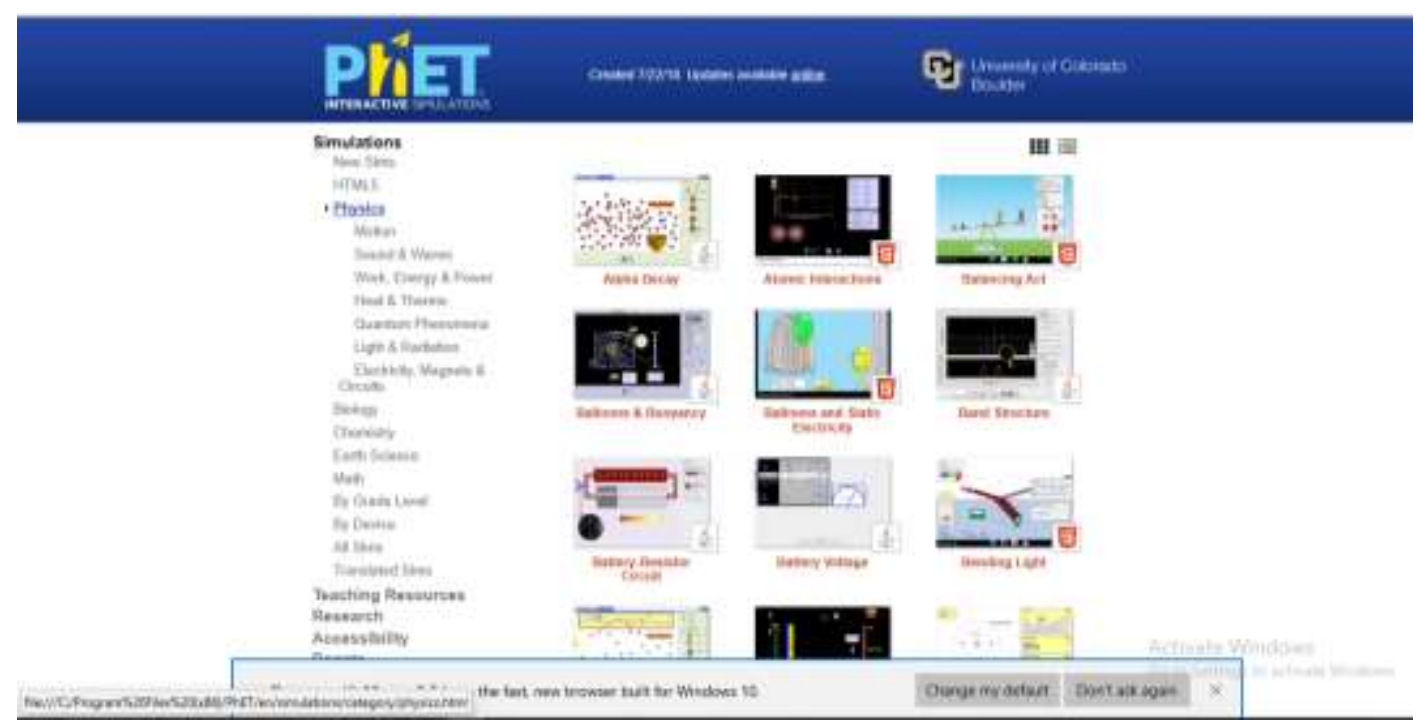

Gambar diatas merupakan topik simulasi yang terdapat pada pelajaran fisika. Pengguna dapat memilih topik yang diinginkan atau yang dibutuhkan. Dalam tampilan aplikasi ini dominan dengan Bahasa Inggris sehingga kita harus mengetahui maksud atau tema dari masing-masing topik simulasi yang diberikan.

6. Jika aplikasi PhET Interactive Simulation telah terbuka dapat diperhatikan pada topiktopik yang disediakan terdapat symbol tertentu. Perhatikan gambar dibawah ini :

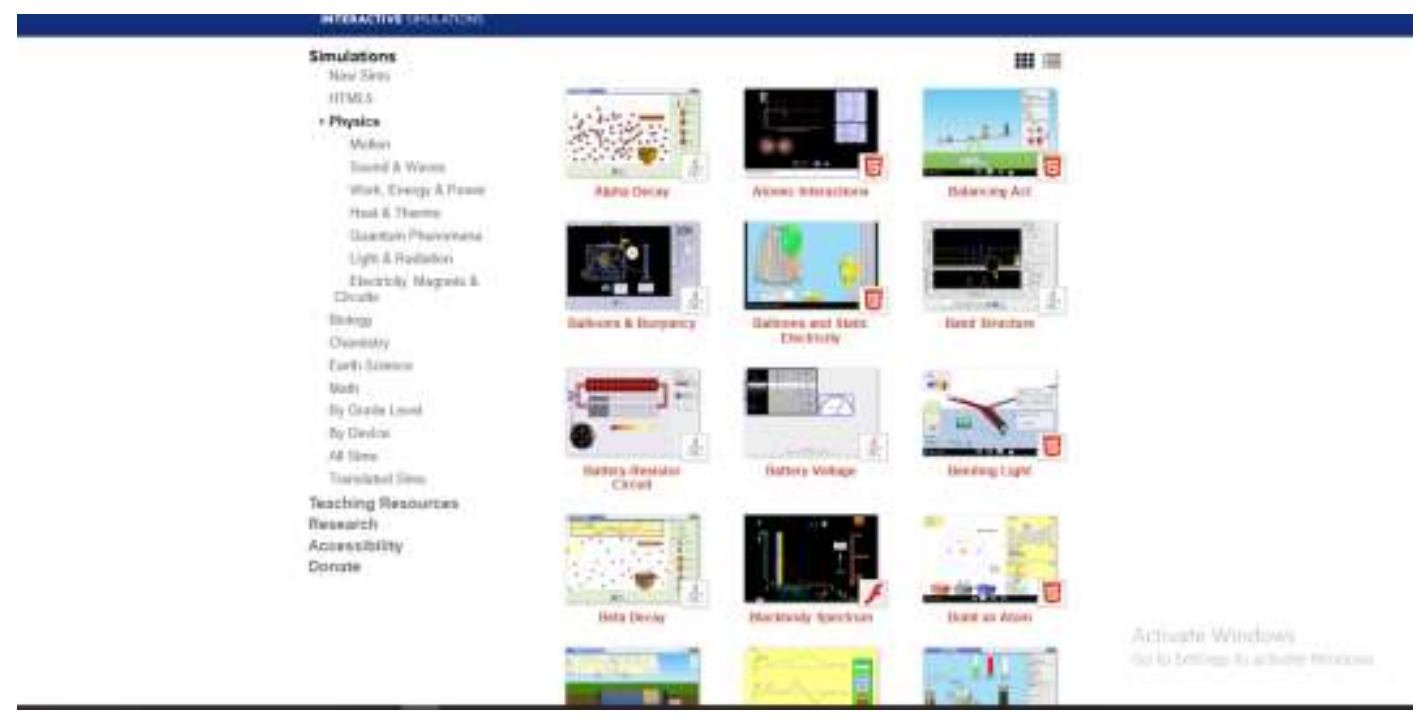

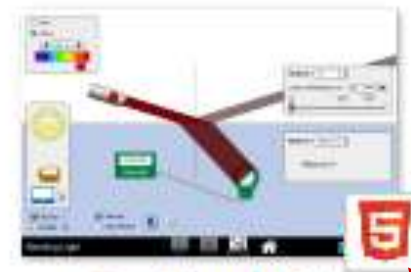

Bending Light

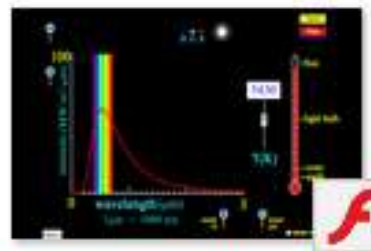

Blackbody Spectrum

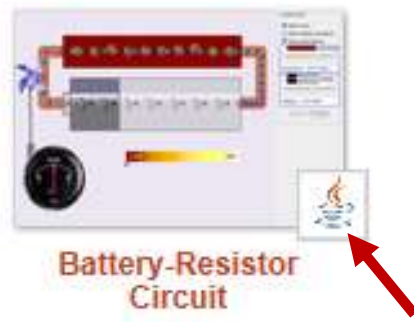

Circuit 
Terdapat 3 tanda pada simulasi PhET Interactive Simulation yaitu "S" (HTML), “F” (Flash Player) dan Java. Adapun langkah-langkah untuk mengakses dari masingmasing tanda adalah sebagai berikut :

I. Jika topik bersimbol " $\boldsymbol{S}$ " (HTML) memberikan makna bahwa simulasi tersebut dapat secara langsung digunakan atau diakses, dengan cara klik topik tersebut maka simulasi tersebut dapat terbuka dan digunakan.

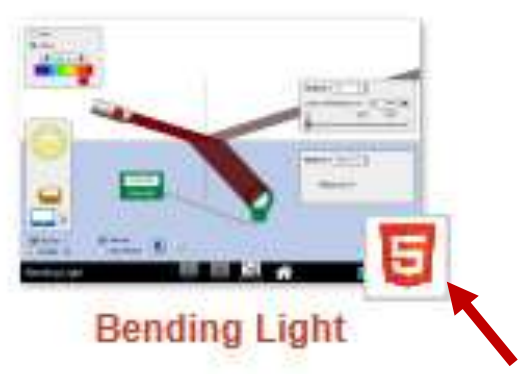

II. Jika topik bersimbol “F” (Flash Player), cara mengaksesnya memerlukan beberapa langkah. Adapun langkah-langkahnya adalah sebagai berikut :

a. Bukalah simulasi tersebut

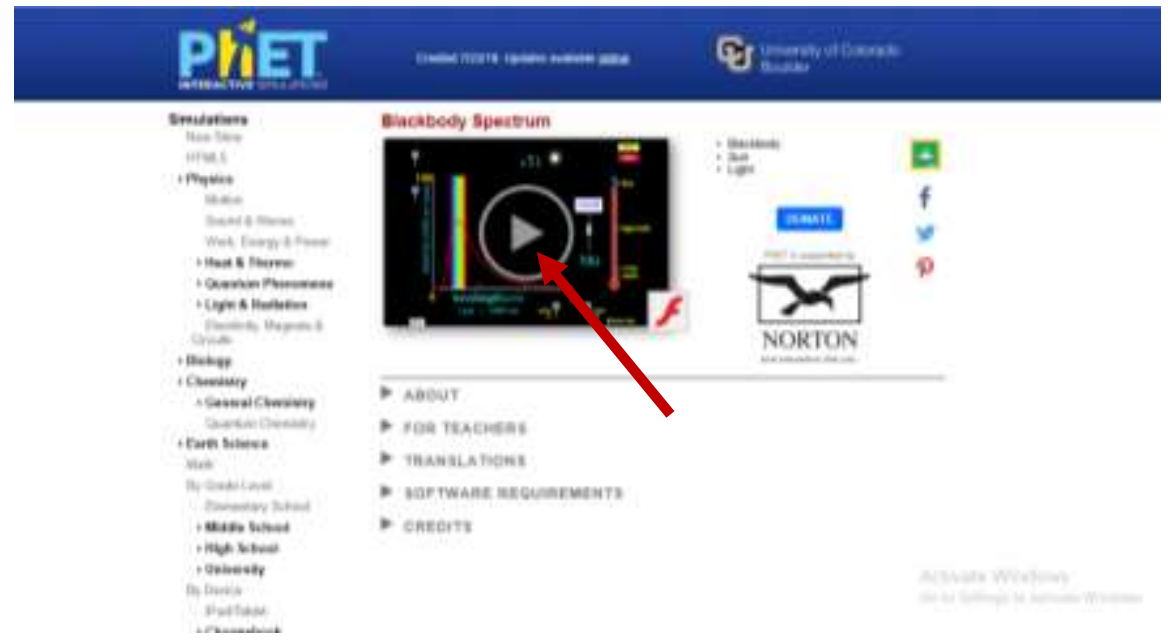

Klik tanda Play pada gambar yang ditunjuk untuk membuka simulasi tersebut

b. Setelah simulasi tersebut terbuka maka akan terlihat tampilan seperti berikut,

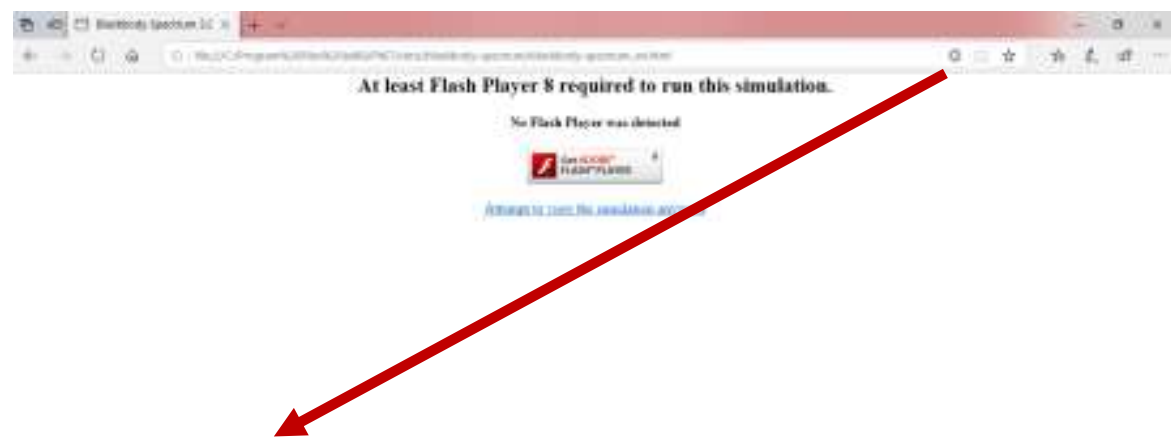




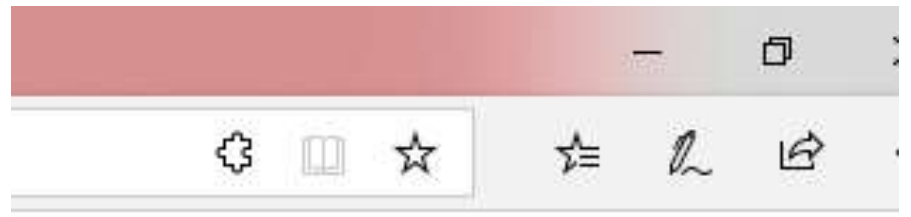

Klik pada bagian yang ditunjuk lalu ikuti tahap selanjutnya

c. Dari tahap sebelumnya setelah di klik maka akan terlihat tampilan seperti berikut,

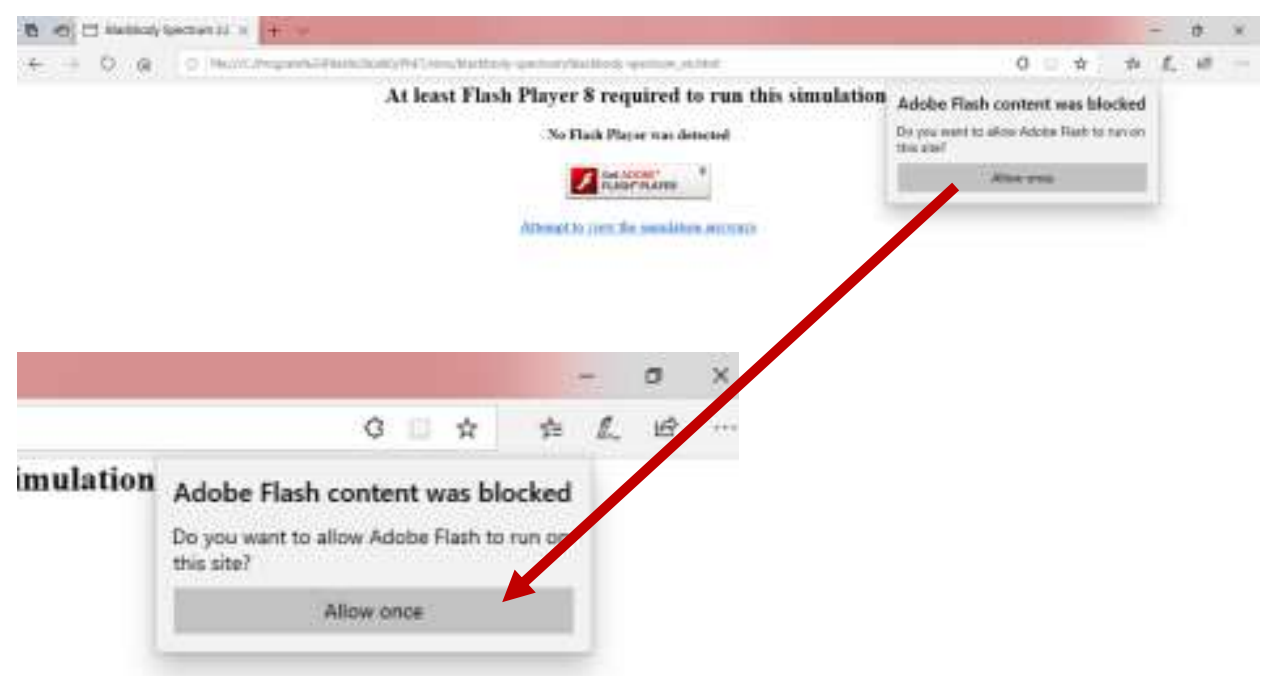

Klik "Allow Once"

d. Setelah memilih "Allow Once" maka simulasi akan terbuka dan dapat digunakan

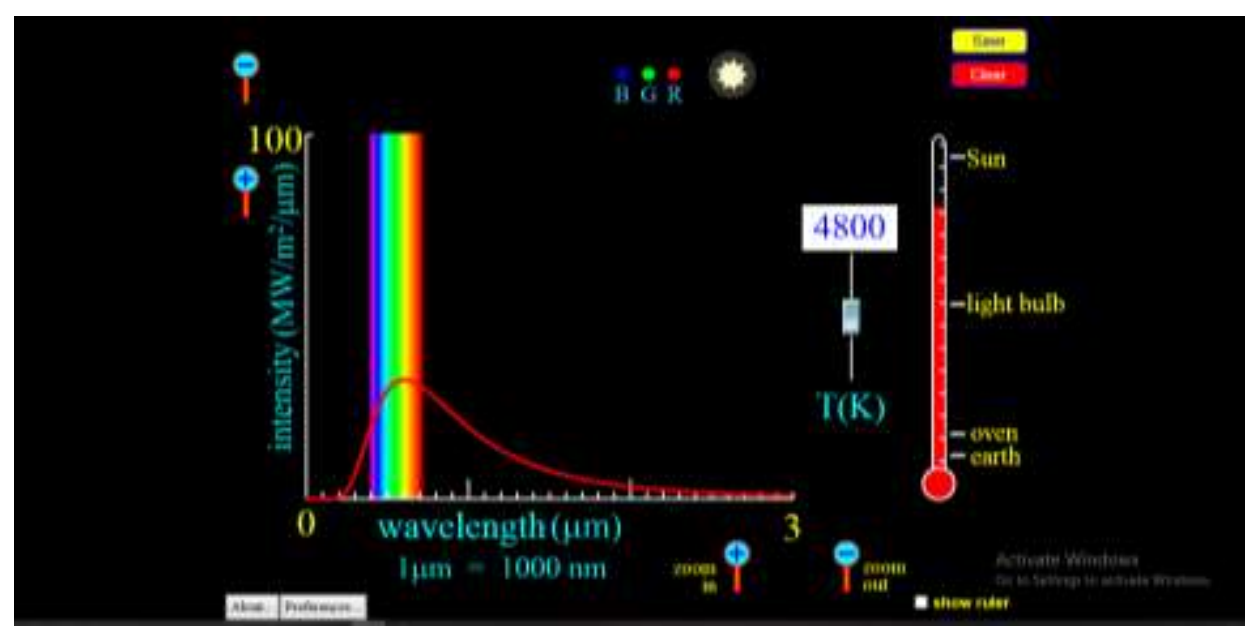

III. Jika terdapat logo Java menandakan bahwa topik tersebut dapat diakses atau dibuka dengan bantuan aplikasi Java. Jika pada leptop atau komputer telah terpasang aplikasi Java maka secara otomatis topik tersebut dapat diakses, dengan cara : 
a. Klik pada gambar yang ditunjuk

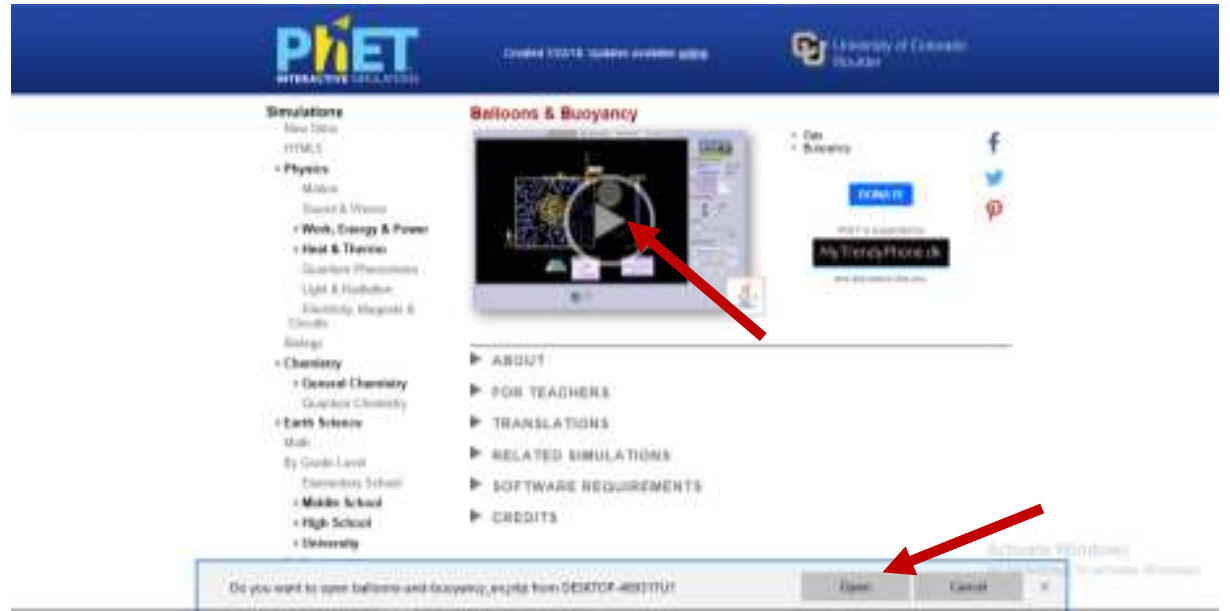

Setelah itu klik “Open” dengan tujuan untuk menyimpan simulasi tersebut. Pada simulasi yang terdapat symbol Java maka simulasi tersebut tidak dapat langsung di akses pada aplikasi PhET Interactive Simulation namun simulasi tersebut akan tersimpan pada file Java pada leptop atau komputer.

b. Ketika memilih "Open" maka akan muncul alamat atau letak simulasi tersebut disimpan, seperti gambar berikut

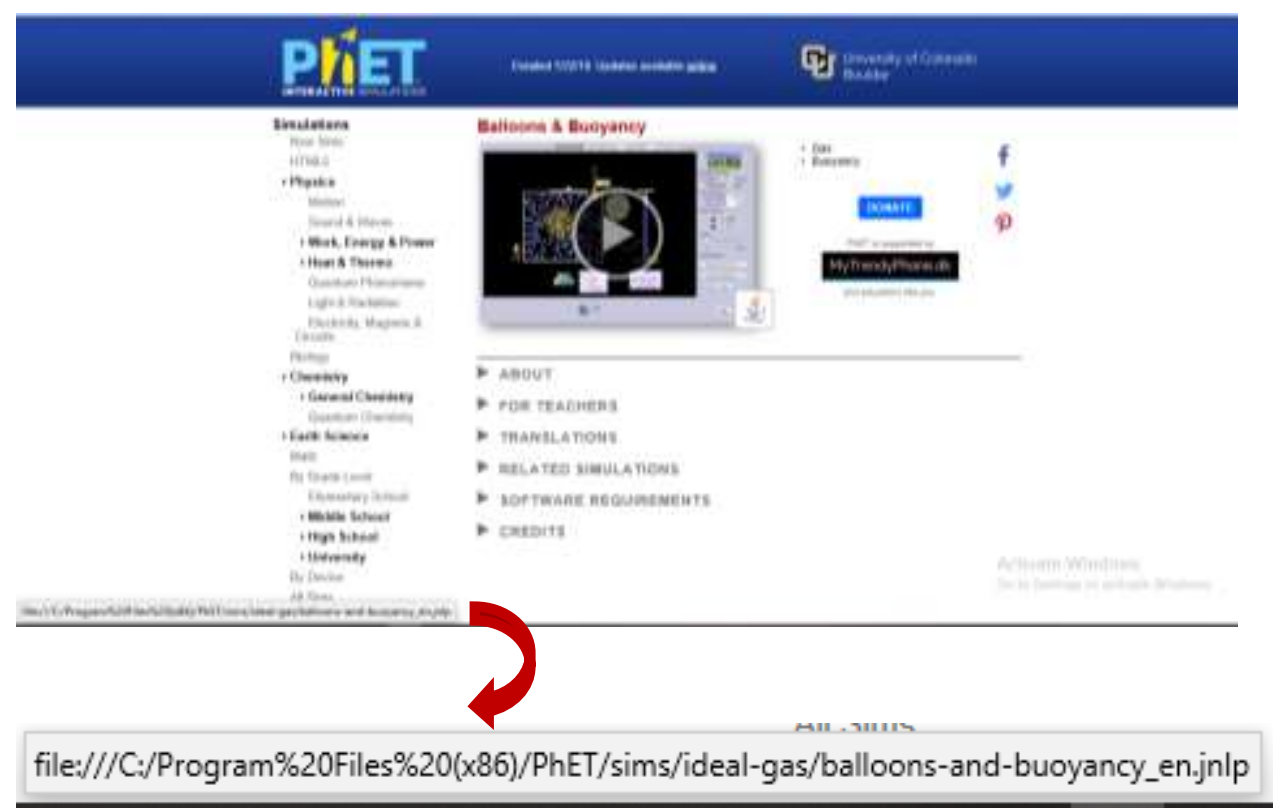

Gambar tersebut menunjukkan tempat tersimpannya simulasi dengan akses Java.

c. Setelah itu bukalah file sesuai dengan petunjuk yang diberikan 


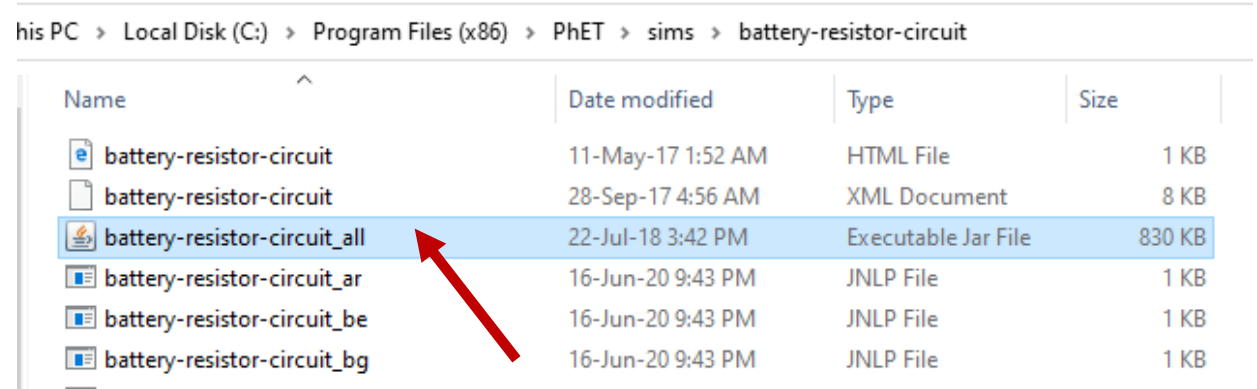

Jika pada file terdapat beberapa pilihan maka yang dapat dibuka yaitu file yang terdapat logo Java sesuai yang ditunjuk.

d. Klik file yang terdapat logo Java sehingga simulagi dapat digunakan

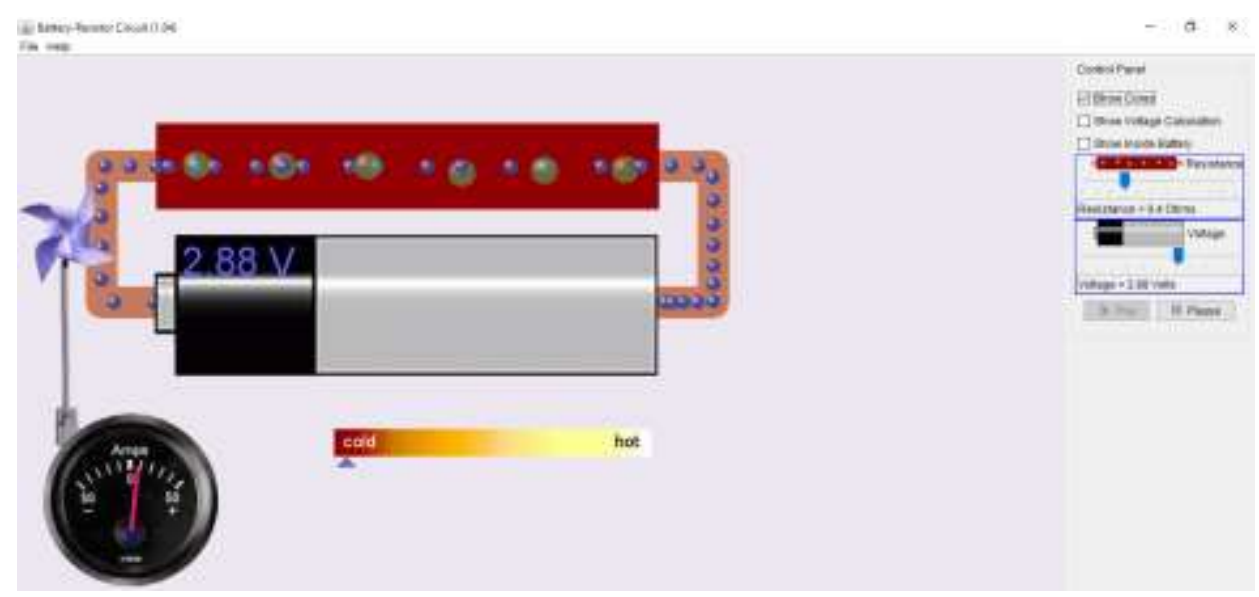

Setelah simulasi dapat dibuka maka telah siap untuk digunakan.

7. Bahasa yang terdapat pada aplikasi PhET Interactive Simulation menggunakan Bahasa Inggris, dapat juga diubah dalam Bahasa lain namun hanya untuk menerjemahkan judul simulasi saja. Jika simulasi telah terbuka maka komponen didalamnya tetap menggunakan Bahasa Inggris. Untuk mengubah judul simulasi pada Bahasa lain maka langkah yang harus dilakukan adalah sebagai berikut :

a. Pilihlah salah satu topik simulasi (bebas memilih topik) 

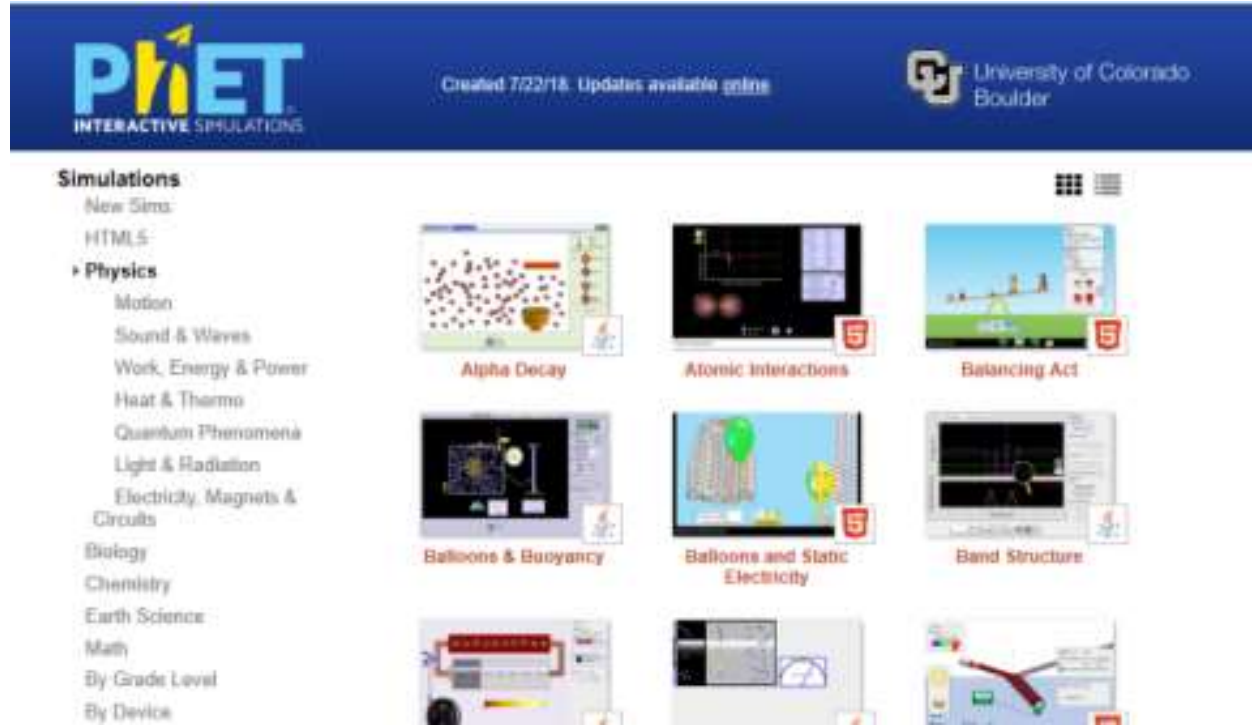

표 트
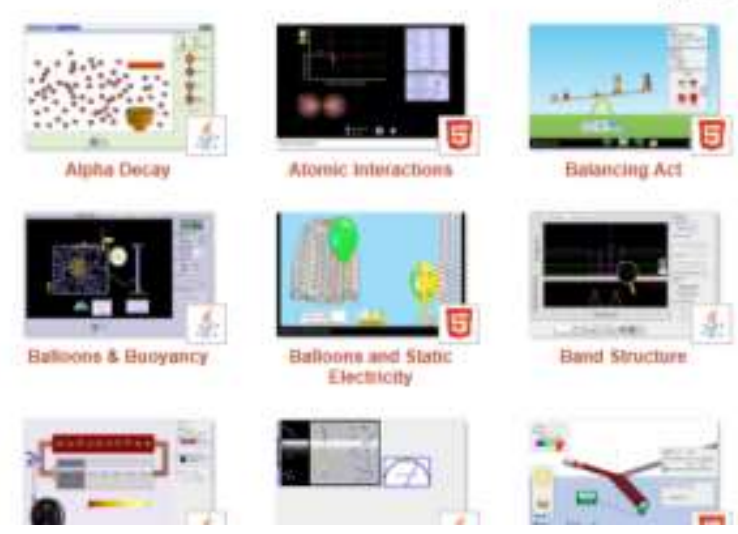

Klik salah satu topik (bebas) lalu ikuti tahap selanjutnya

b. Setelah itu maka akan terdapat tampilan sebagai berikut

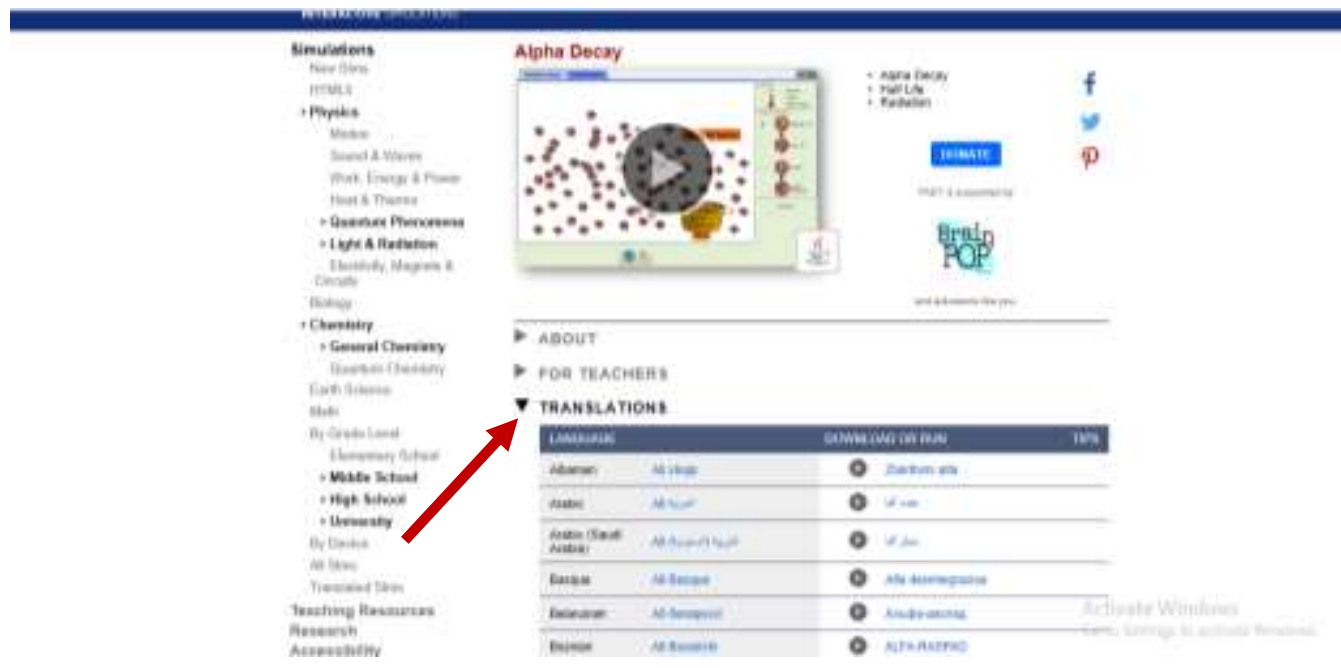

Klik “Translation” maka akan terdapat banyak pilihan Bahasa, termasuk Bahasa Indonesia. Perubahan Bahasa ini hanya pada judul topik simulasi saja. 


\section{BAB IV \\ CONTOH PENGGUNAAN PHET PADA PRAKTIKUM IPA SMP}

Pada pembahasan ini akan dijabarkan langkah-langkah yang harus dilakukan dalam menggunakan aplikasi PhET Interactive Simulation sebagai media pembelajaran. Ketika melakukan simulasi melalui aplikasi PhET Interactive Simulation maka pelaku atau pengguna seolah-olah berada dalam laboratorium. Peggunaan aplikasi ini seperti layaknya seseorang yang sedang bermain game sehingga menimbulkan rasa senang bagi penggunanya.

Ketika menggunakan simulasi melalui aplikasi PhET Interactive Simulation maka kita harus mengetahui komponen yang ada pada simulasi tersebut agar mempermudah kita dalam menggunakan aplikasi tersebut. Agar lebih memperjelas penggunaan aplikasi PhET Interactive Simulation maka akan diberikan contoh cara penggunaan aplikasi PhET Interactive Simulation. Adapun langkah-langkahnya adalah sebagai berikut :

1. Materi yang akan digunakan kali ini adalah cahaya. Akan diberikan simulasi tentang sifat-sifat cahaya yaitu cahaya dapat dipantulkan

2. Buka program software simulasi PhET Interactive Simulation lalu klik Play whit Simulations
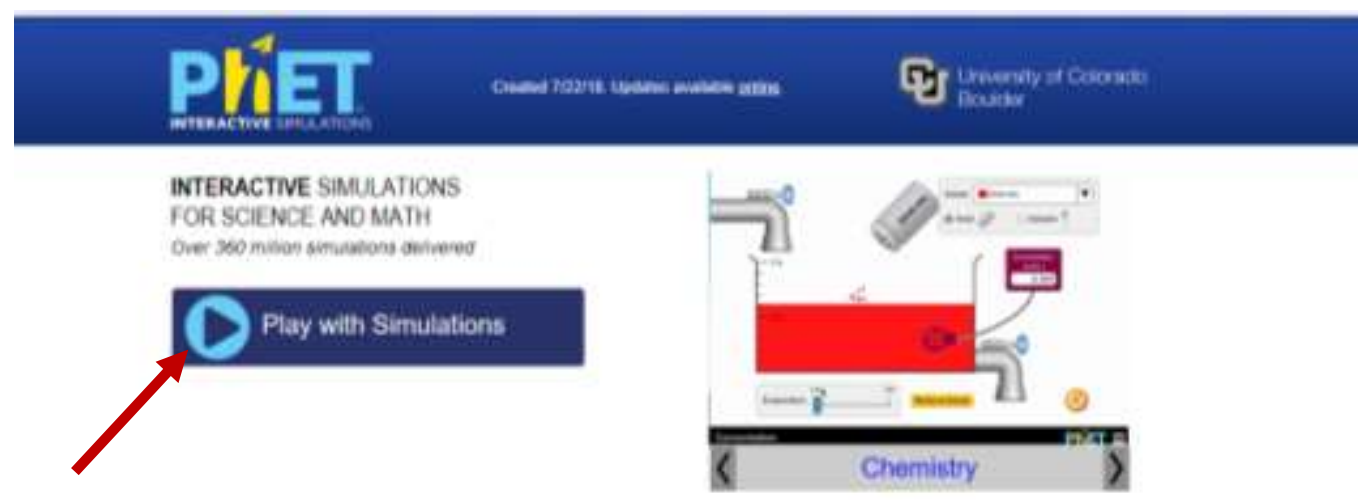

3. Pilih Physics 


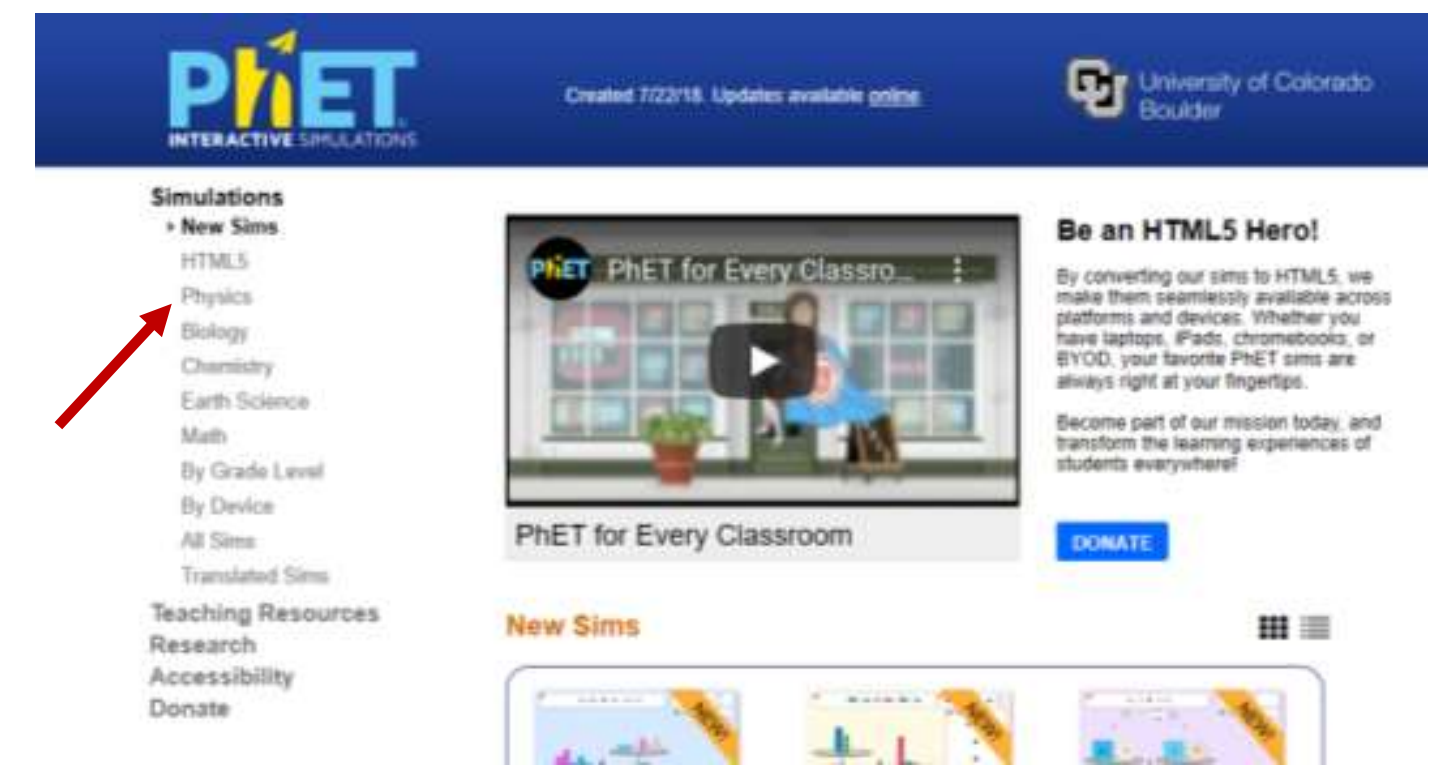

4. Pilihlah Bending Light

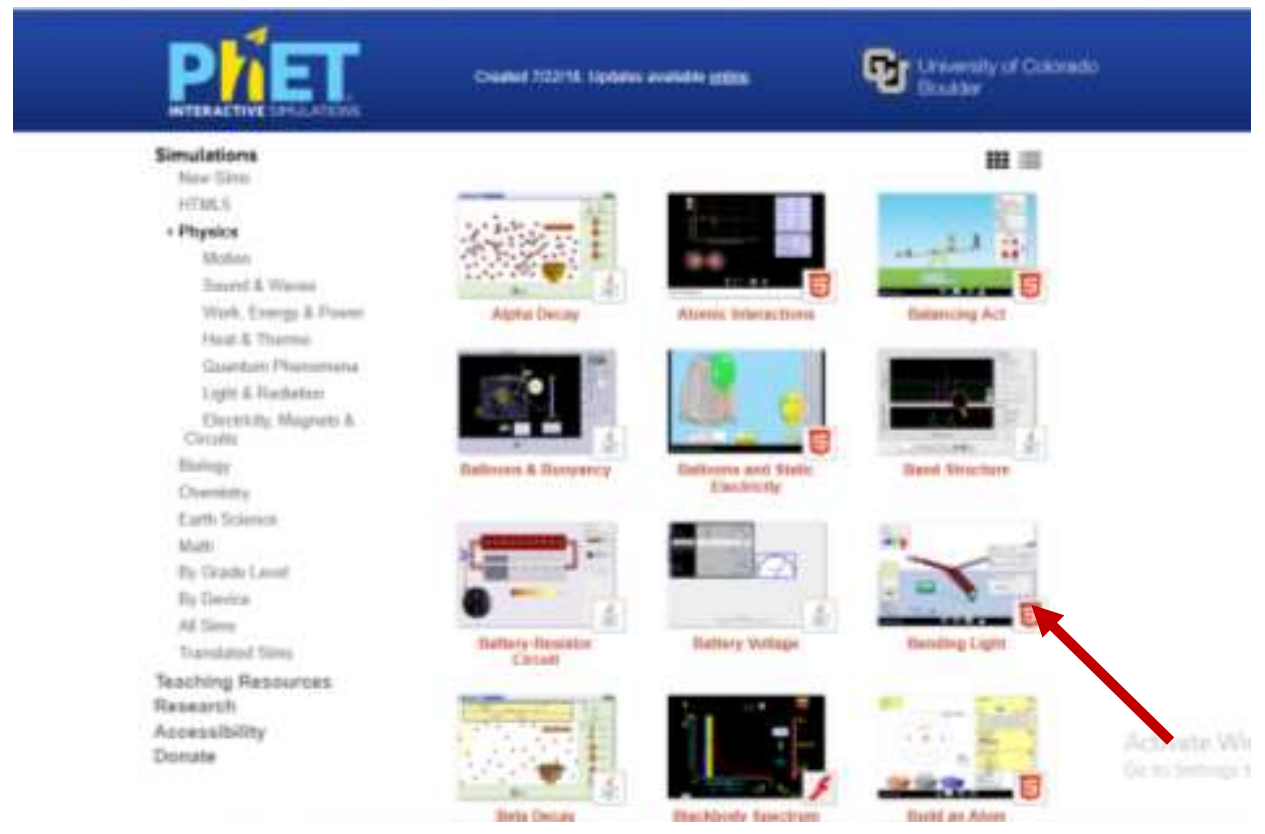

5. Buka simulasi Bending Light dengan cara klik gambar yang ditunjuk

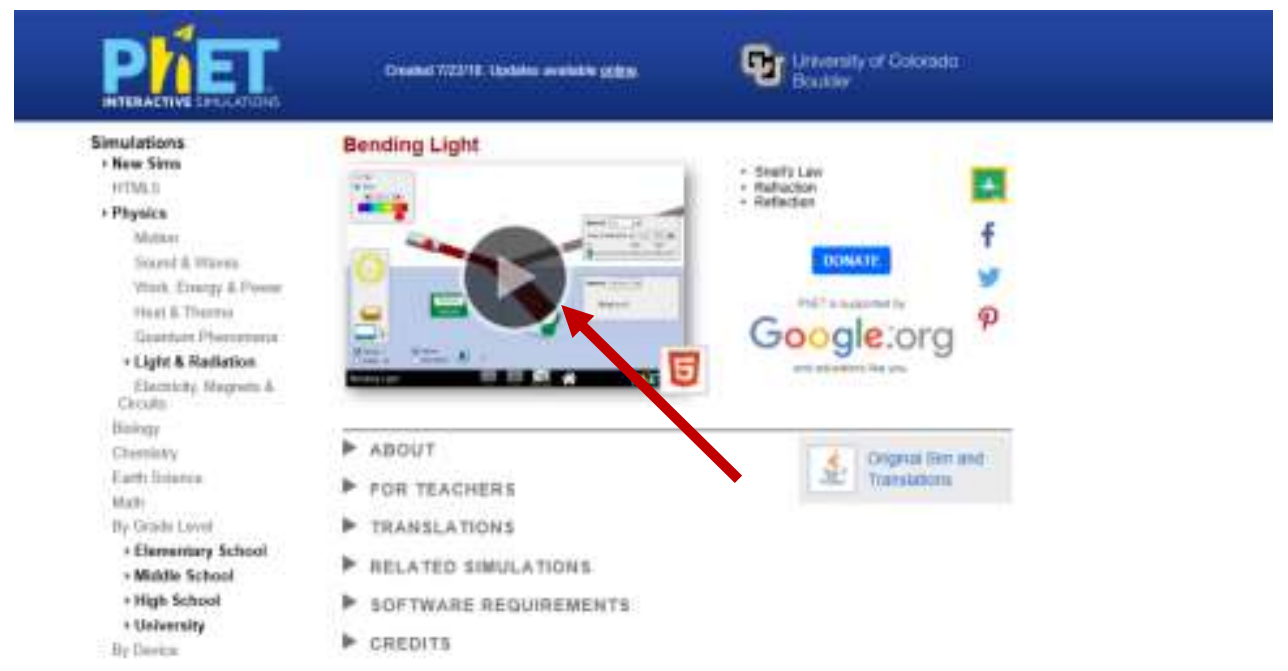


6. Pilih Intro

\section{Bending Light}
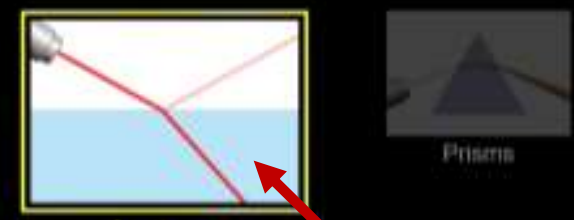

Prismin

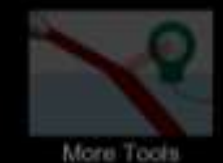

Intro

7. Setelah memilih Intro maka akan terdapat tampilan berikut,

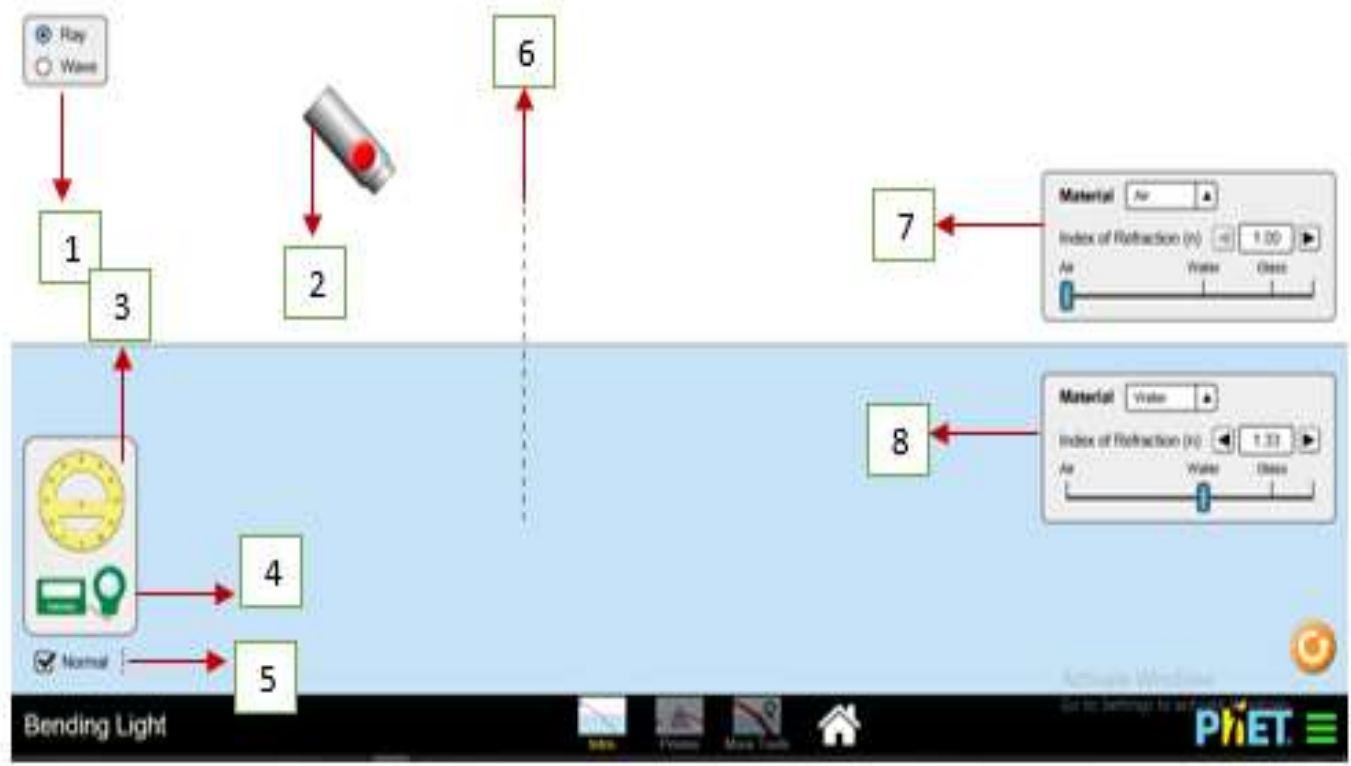

Keterangan :

1 : Menunjukkan sinar yang akan dikeluarjan pada sumber cahaya. Terdapat pilihan Ray (garis lurus) dan Wave (garis berjalan)

2 : Sumber cahaya

3 : Busur

$4 \quad$ : Intensitas

5 : Pengaturan garis normal. Jika dicentang maka garis normal muncul, jika dikosongkan maka tidak terdapat garis normal

6 : Garis normal

$7 \quad$ : Material atas

$8 \quad$ : Material bawah 
Gambar diatas merupakan tampilan pada bagian Intro pada Bending Light. Sebelum melakukan simulasi hedaknya perlu dipahami makna dari komponen-komponen yang ada dalam tampilan tersebut. Jika telah dipahami komponen didalamnya maka akan mudah untuk menggunakannya.

8. Untuk mensimulasikan cahaya dapat dipantulkan maka terlebih dahulu atur material atas dan bawahnya. Gunakan material atas (Mystery A) dan material bawah (Water)
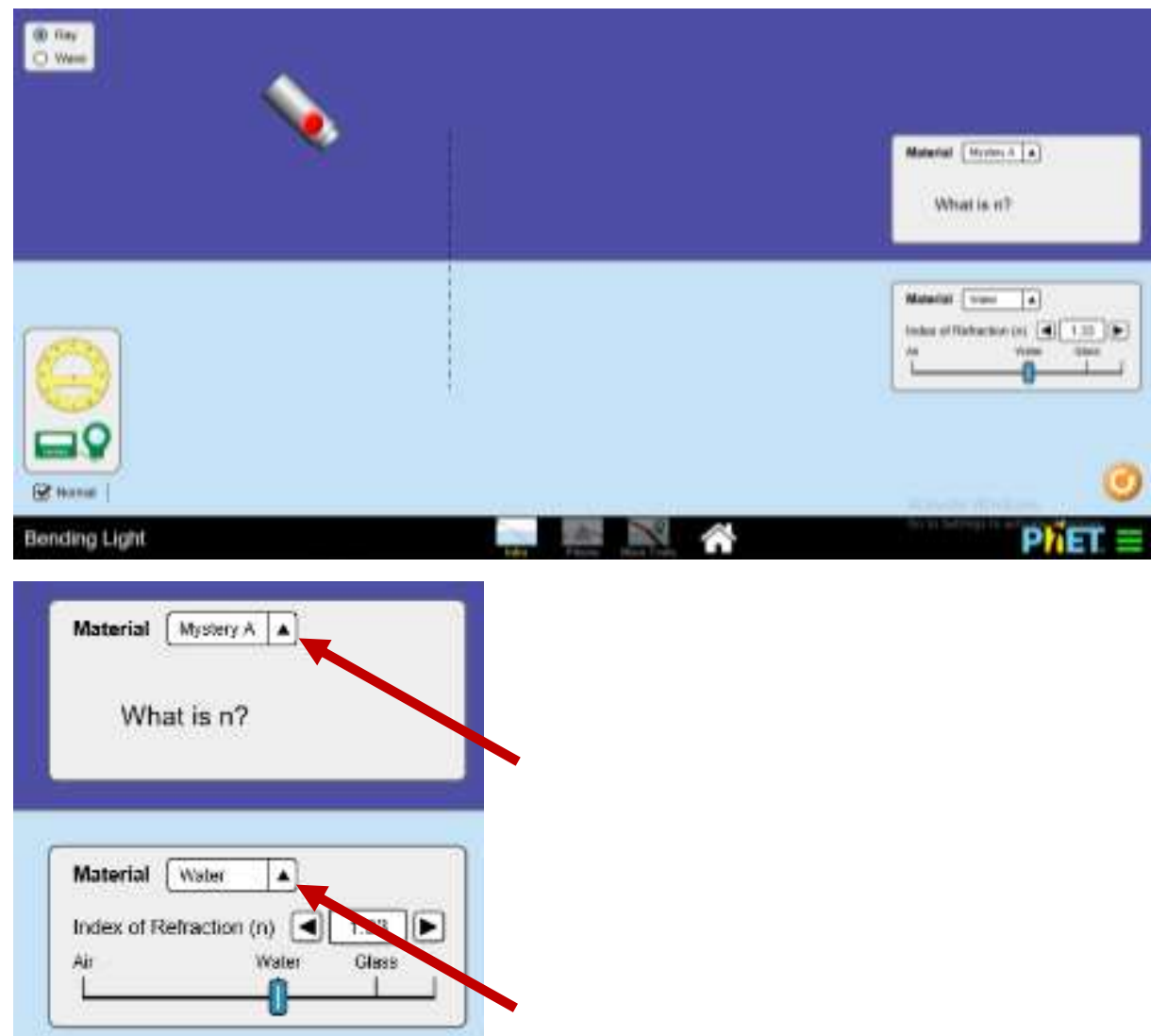

9. Tekan tombol merah pada leser

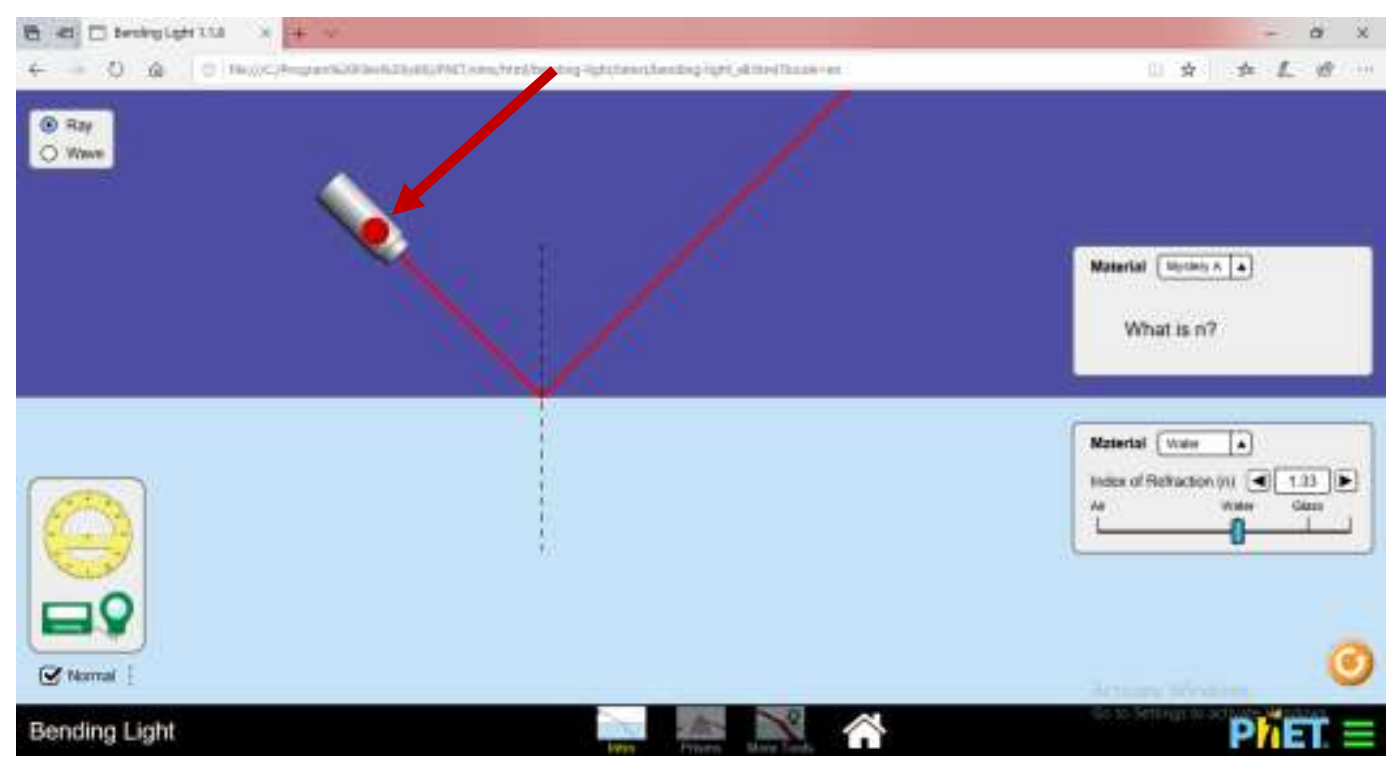


10. Letakkan busur dengan menggeser busur pada garis normal, setelah itu atur besar sudut sesuai dengan yang diinginkan

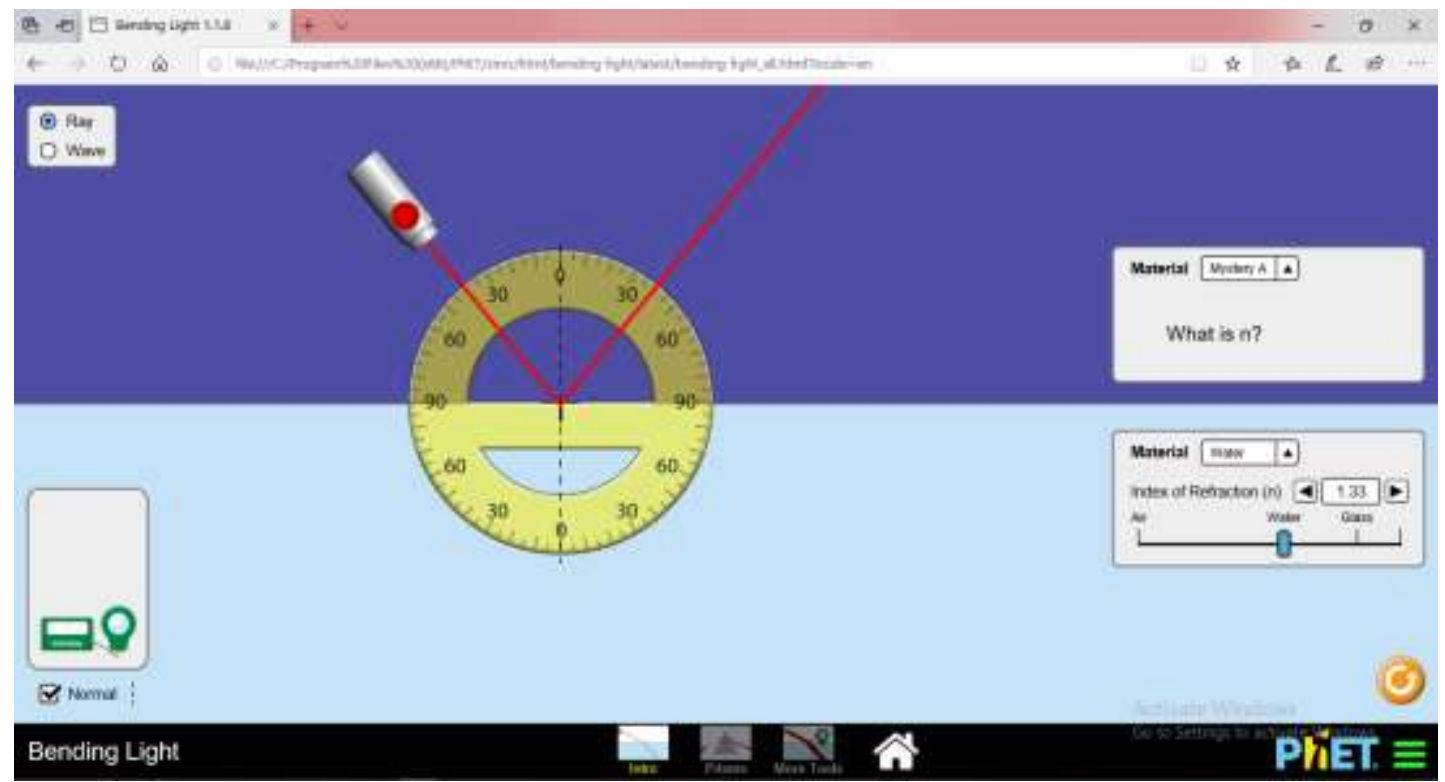

11. Setelah busur diletakkan maka dapat dianalisis bahwa besar sudut datang dan sudut pantul adalah sama, sesuai dengan Hukum Snellius "Sinar datang, sinar pantul dan garis normal terletak pada satu bidang datar. Sudut datang sama dengan sudut pantul"

12. Selesai 


\section{BAB V}

\section{PEMETAAN MATA PRAKTIKUM IPA DAN MATEMATIKA SMP}

\section{A. Pemetaan Praktikum IPA sesuai Kompetensi Dasar IPA SMP}

\begin{tabular}{|c|c|c|}
\hline Kelas & $\begin{array}{l}\text { Kompetensi } \\
\text { Dasar }\end{array}$ & Nama Mata Praktikum IPA \\
\hline \multirow[t]{11}{*}{ VII } & $3.1 ; 4.1$ & $\begin{array}{l}\text { Pengukuran (panjang, massa, dan waktu) dengan } \\
\text { menggunakan alat ukur baku dan tidak baku }\end{array}$ \\
\hline & $3.2 ; 4.2$ & $\begin{array}{l}\text { Mengamati ciri-ciri makhluk hidup: Monera, Protista, Fungi, } \\
\text { Plantae, Animalia }\end{array}$ \\
\hline & $3.3 ; 4.3$ & $\begin{array}{l}\text { Teknik pemisahan campuran: Penyulingan, Kromatografi, } \\
\text { Penyubliman }\end{array}$ \\
\hline & $3.4 ; 4.4$ & Suhu, pemuaian, dan perpindahan kalor \\
\hline & $3.5 ; 4.5$ & Perubahan bentuk energi, fotosintesis, respirasi \\
\hline & $3.6 ; 4.6$ & $\begin{array}{l}\text { Mengamati torso manusia dan hewan: ikan/ katak/ burung/ } \\
\text { kadal; mengamati dengan mikroskop sel, jaringan, organ, dan } \\
\text { sistem organ }\end{array}$ \\
\hline & $3.7 ; 4.7$ & $\begin{array}{l}\text { Pertumbuhan populasi terhadap kesediaan ruang dan lahan } \\
\text { pertanian, interaksi antara komponen biotik dan abiotik }\end{array}$ \\
\hline & $3.8 ; 4.8$ & Pencemaran air, pencemaran udara, dan pencemaran tanah \\
\hline & $3.9 ; 4.9$ & Pengaruh suhu dan $\mathrm{CO}_{2}$ (model rumah kaca) \\
\hline & $3.10 ; 4.10$ & $\begin{array}{l}\text { Pengamatan aktivitas gunung berapi, gempa bumi, dan tsunami } \\
\text { serta mitigasi bencana alam }\end{array}$ \\
\hline & $3.11 ; 4.11$ & $\begin{array}{l}\text { Pengamatan rotasi dan revolusi bumi dan dampak yang } \\
\text { ditimbulkannya }\end{array}$ \\
\hline \multirow[t]{12}{*}{ VIII } & $3.1 ; 4.1$ & $\begin{array}{l}\text { Mengamati struktur dan fungsi rangka, sendi dan otot manusia; } \\
\text { percobaan untuk mengetahui struktur gerak, jenis dan } \\
\text { perbedaan serta mekanisme kerja jaringan otot }\end{array}$ \\
\hline & $3.2 ; 4.2$ & GLB dan GLBB (aplikasi Hukum Newton) \\
\hline & $3.3 ; 4.3$ & $\begin{array}{l}\text { Pesawat Sederhana dan hubungan kerja otot pada struktur } \\
\text { rangka manusia }\end{array}$ \\
\hline & $3.4 ; 4.4$ & $\begin{array}{l}\text { Mengamati struktur dan fungsi tumbuhan dan inspirasi } \\
\text { teknologinya }\end{array}$ \\
\hline & $3.5 ; 4.5$ & $\begin{array}{l}\text { Uji bahan makanan: karobohidrat, gula, lemak, dan protein; } \\
\text { pencernaan mekanis dan kimiawi }\end{array}$ \\
\hline & $3.6 ; 4.6$ & $\begin{array}{l}\text { Zat-zat aditif pada makanan dan minuman; jenis-jenis zat aditif } \\
\text { dan adiktif serta dampaknya }\end{array}$ \\
\hline & $3.7 ; 4.7$ & Sistem peredaran darah \\
\hline & $3.8 ; 4.8$ & Tekanan zat padat, zat cair, dan zat gas \\
\hline & $3.9 ; 4.9$ & Sistem pernapasan \\
\hline & $3.10 ; 4.10$ & Sistem ekskresi \\
\hline & $3.11 ; 4.11$ & $\begin{array}{l}\text { Periode dan getaran bandul ayunan sederhana; gelombang } \\
\text { pada slinki/ tali; frekuensi bunyi dan resonansi (sistem } \\
\text { sonar pada hewan) }\end{array}$ \\
\hline & $3.12 ; 4.12$ & Pembentukan bayangan pada cermin dan lensa \\
\hline \multirow[t]{2}{*}{ IX } & $3.1 ; 4.1$ & Mengamati carta pembelahan sel \\
\hline & $3.2 ; 4.2$ & Mengamati reproduksi hewan dan tumbuhan \\
\hline
\end{tabular}




\begin{tabular}{|c|c|c|}
\hline Kelas & $\begin{array}{l}\text { Kompetensi } \\
\text { Dasar }\end{array}$ & Nama Mata Praktikum IPA \\
\hline & $3.3 ; 4.3$ & Pemodelan persilangan monohibrid dan dihibrid \\
\hline & $3.4 ; 4.4$ & Menyelidiki muatan listrik statis dan interaksinya \\
\hline & $3.5 ; 4.5$ & $\begin{array}{l}\text { Rangkaian listrik: hubungan kuat arus, hambatan, dan } \\
\text { tegangan listrik; mengukur kuat arus listrik yang mengalir } \\
\text { pada rangkaian hambatan seri dan parallel. }\end{array}$ \\
\hline & $3.6 ; 4.6$ & $\begin{array}{l}\text { Menyelidiki sifat magnet dan pembuatan magnet; faktor- } \\
\text { faktor yang menyebabkan gaya Lorentz }\end{array}$ \\
\hline & $3.7 ; 4.7$ & $\begin{array}{l}\text { Membuat produk bioteknologi konvensional: tape, tempe, } \\
\text { yogurt }\end{array}$ \\
\hline & $3.8 ; 4.8$ & Model atom \\
\hline & $3.9 ; 4.9$ & $\begin{array}{l}\text { Peran tanah bagi kehidupan; mengidentifikasi penyusun tanah } \\
\text { dan tingkat kesuburan tanah }\end{array}$ \\
\hline & $3.10 ; 4.10$ & $\begin{array}{l}\text { Dampak teknologi yang tidak ramah lingkungan terhadap } \\
\text { lingkungan alam }\end{array}$ \\
\hline
\end{tabular}

\section{B. Daftar Mata Praktikum IPA di Aplikasi PhET}

\begin{tabular}{|c|l|l|l|l|}
\hline No & Nama Mata Praktikum & \multicolumn{1}{|c|}{ Materi } & Kelas & \multicolumn{1}{|c|}{ Ket } \\
\hline 1 & Massa Jenis & $\begin{array}{l}\text { Massa jenis, massa, } \\
\text { volume }\end{array}$ & VII-1 & Flash \\
\hline 2 & $\begin{array}{l}\text { Perpindahan Kalor secara } \\
\text { Konduksi }\end{array}$ & $\begin{array}{l}\text { Konduktivitas, Tingkat } \\
\text { energi, konduktor cahaya }\end{array}$ & VII-1 & Java \\
\hline 3 & $\begin{array}{l}\text { Bentuk dan Perubahan } \\
\text { Energi }\end{array}$ & $\begin{array}{l}\text { Energi, konservasi energi, } \\
\text { energi sistem }\end{array}$ & VII-1 & Java \\
\hline 5 & Energi: Skate Dasar & $\begin{array}{l}\text { Energi, konservasi energi, } \\
\text { energi kinetik }\end{array}$ & VII-1 & Java \\
\hline 5 & $\begin{array}{l}\text { Energi: } \text { Sktate Board } \\
\text { Lengkung }\end{array}$ & $\begin{array}{l}\text { Energi, konservasi energi, } \\
\text { energi kinetik }\end{array}$ & VII-1 & Java \\
\hline 7 & $\begin{array}{l}\text { Lempe effect }) \\
8\end{array}$ & $\begin{array}{l}\text { Sistem Tata Surya } \\
\text { Panas, efek rumah kaca }\end{array}$ & VII-2 & Java \\
\hline 9 & Gravitasi dan Orbit & $\begin{array}{l}\text { Lempeng tektonik, kerak } \\
\text { bumi, dan litosfer }\end{array}$ & VII-2 & Java \\
\hline 10 & Gerak, kecepatan, & VII-2 & Flash \\
\hline 11 & $\begin{array}{l}\text { Gercepatan } \\
\text { Gerak gravitasi, gerak }\end{array}$ & VII-2 dimensi) & $\begin{array}{l}\text { Gerak, kecepatan, } \\
\text { percepatan }\end{array}$ & Flash \\
\hline 12 & $\begin{array}{l}\text { Gaya dan Gerak pada } \\
\text { Bidang Datar }\end{array}$ & $\begin{array}{l}\text { Gaya, kedudukan, } \\
\text { kecepatan }\end{array}$ & VIII-1 & Java \\
\hline 13 & $\begin{array}{l}\text { Gaya dan Gerak pada } \\
\text { Bidang Miring }\end{array}$ & $\begin{array}{l}\text { Gaya, kedudukan, dan } \\
\text { kecepatan }\end{array}$ & Java \\
\hline 14 & Bidang Miring & Gaya, energi, kerja & VIII-1 & Java \\
\hline 15 & Tuas & Keseimbangan, lengan & VIII-1 & Java/Flash \\
\hline
\end{tabular}




\begin{tabular}{|c|c|c|c|c|}
\hline No & Nama Mata Praktikum & Materi & Kelas & Ket \\
\hline 16 & Wujud Zat & $\begin{array}{l}\text { Cair, padat, gas, ikatan } \\
\text { kimia }\end{array}$ & VIII-2 & Java \\
\hline 17 & Tekanan Gas & $\begin{array}{l}\text { Gas, panas, } \\
\text { thermodinamika }\end{array}$ & VIII-2 & Java \\
\hline 18 & Tekanan Air & Tekanan, fluida & VIII-2 & Java \\
\hline 19 & Bandul sederhana & $\begin{array}{l}\text { Gerak harmonis sederhana, } \\
\text { konservasi energi }\end{array}$ & VIII-2 & Java \\
\hline 20 & Gelombang pada tali & $\begin{array}{l}\text { Gelombang, frekuensi, } \\
\text { amplitudo }\end{array}$ & VIII-2 & Java/Flash \\
\hline 21 & Massa dan Pegas & $\begin{array}{l}\text { Pegas, Hukum Hooke, dan } \\
\text { konservasi energi }\end{array}$ & VIII-2 & Java \\
\hline 22 & Resonansi & $\begin{array}{l}\text { Resonansi, gerak } \\
\text { harmonis, getaran }\end{array}$ & VIII-2 & Java/Flash \\
\hline 23 & Gelombang Radio & Gelombang radio & VIII-2 & Java \\
\hline 24 & Gelombang Suara & Suara, gelombang & VIII-2 & Java \\
\hline 25 & Tampilan Warna Cahaya & $\begin{array}{l}\text { Foton, cahaya } \\
\text { monokromatik, cahaya } \\
\text { putih }\end{array}$ & VIII-2 & Java \\
\hline 26 & Optika Geometri & Refraksi, lensa, optik & VIII-2 & Java/Flash \\
\hline 27 & $\begin{array}{l}\text { Pembiasan/ Pembelokan } \\
\text { Cahaya }\end{array}$ & $\begin{array}{l}\text { Hukum Snell, Cahaya, } \\
\text { Pembiasan }\end{array}$ & VIII-2 & Java \\
\hline 28 & Seleksi Alam & $\begin{array}{l}\text { Genetik, seleksi alam, } \\
\text { evolusi }\end{array}$ & IX-1 & Java \\
\hline 29 & Balon dan Listrik Statis & $\begin{array}{l}\text { Listrik statis, muatan } \\
\text { listrik, dan gaya listrik }\end{array}$ & IX-1 & Java \\
\hline 30 & $\begin{array}{l}\text { Pembangkit Listrik Statis } \\
\text { John Travoltage }\end{array}$ & Listrik statis & IX-1 & Java \\
\hline 31 & Gambaran Medan Listrik & $\begin{array}{l}\text { Kelistrikan, muatan listrik, } \\
\text { medan listrik }\end{array}$ & IX-1 & Java \\
\hline 32 & Hukum Ohm & Hukum Ohm, sirkuit & IX-1 & Java \\
\hline 33 & Rangkaian Listrik DC & Sirkuit, lampu, baterai & IX-1 & Java \\
\hline 34 & Rangkaian Baterai-Resistor & Resistor, tegangan, baterai & IX-1 & Java \\
\hline 35 & Muatan dan Medan Listrik & $\begin{array}{l}\text { Muatan listrik, medan } \\
\text { listrik, potensial listrik }\end{array}$ & IX-1 & Java \\
\hline 36 & Magnet dan Elektromagnet & $\begin{array}{l}\text { Magnet, medan magnet, } \\
\text { elektromagnet }\end{array}$ & IX-2 & Java \\
\hline 37 & Magnet dan Kompas & $\begin{array}{l}\text { Magnet, medan magnet, } \\
\text { kompas }\end{array}$ & IX-2 & Java \\
\hline 38 & Atom & $\begin{array}{l}\text { Atom, struktur atom, } \\
\text { simbol isotop }\end{array}$ & IX-2 & Java \\
\hline 39 & Molekul & $\begin{array}{l}\text { Atom, molekul, membuat } \\
\text { formula molekul }\end{array}$ & IX-2 & Java \\
\hline 40 & Bentuk Molekul Dasar & Molekul, atom, ikatan & IX-2 & Java \\
\hline
\end{tabular}


C. Pemetaan Praktikum Matematika sesuai Kompetensi Dasar SMP

\begin{tabular}{|c|c|c|}
\hline Kelas & $\begin{array}{l}\text { Kompete } \\
\text { nsi Dasar }\end{array}$ & Nama Kegiatan di Mapel Matematika \\
\hline \multirow[t]{12}{*}{ VII } & $3.1 ; 4.1$ & $\begin{array}{l}\text { Menyelesaikan masalah yang berkaitan dengan urutan } \\
\text { beberapa bilangan bulat dan pecahan (biasa, campuran, } \\
\text { desimal, persen). }\end{array}$ \\
\hline & $3.2 ; 4.2$ & $\begin{array}{l}\text { Menyelesaikan masalah yang berkaitan dengan operasi } \\
\text { hitung bilangan bulat dan pecahan. }\end{array}$ \\
\hline & $3.3 ; 4.3$ & $\begin{array}{l}\text { Menyelesaikan masalah yang berkaitan dengan bilangan dalam } \\
\text { bentuk bilangan berpangkat bulat positif dan negatif. }\end{array}$ \\
\hline & $3.4 ; 4.4$ & $\begin{array}{l}\text { Menyelesaikan masalah kontekstual yang berkaitan dengan } \\
\text { himpunan, himpunan bagian, himpunan semesta, himpunan } \\
\text { kosong, komplemen himpunan dan operasi biner pada } \\
\text { himpunan. }\end{array}$ \\
\hline & $3.5 ; 4.5$ & $\begin{array}{l}\text { Menyelesaikan masalah yang berkaitan dengan bentuk } \\
\text { aljabar dan operasi pada bentuk aljabar. }\end{array}$ \\
\hline & $3.6 ; 4.6$ & $\begin{array}{l}\text { Menyelesaikan masalah yang berkaitan dengan persamaan } \\
\text { dan pertidaksamaan linear satu variabel. }\end{array}$ \\
\hline & $3.7 ; 4.7$ & $\begin{array}{l}\text { Menyelesaikan masalah yang berkaitan dengan rasio dua } \\
\text { besaran (satuannya sama dan berbeda). }\end{array}$ \\
\hline & $3.8 ; 4.8$ & $\begin{array}{l}\text { Menyelesaikan masalah yang berkaitan dengan perbandingan } \\
\text { senilai dan berbalik nilai. }\end{array}$ \\
\hline & $3.9 ; 4.9$ & $\begin{array}{l}\text { Menyelesaikan masalah berkaitan dengan aritmatika sosial } \\
\text { (penjualan, pembelian, potongan, keuntungan, kerugian, } \\
\text { bunga tunggal, persentase, bruto, neto, tara). }\end{array}$ \\
\hline & $3.10 ; 4.10$ & $\begin{array}{l}\text { Menyelesaikan masalah yang berkaitan dengan hubungan antar } \\
\text { sudut sebagai akibat dari dua garis sejajar yang dipotong oleh } \\
\text { garis transversal. }\end{array}$ \\
\hline & $3.11 ; 4.11$ & $\begin{array}{l}\text { Menyelesaikan masalah kontekstual yang berkaitan dengan luas } \\
\text { dan keliling segiempat (persegi, persegipanjang, belahketupat, } \\
\text { jajargenjang, trapesium, dan layanglayang) dan segitiga. }\end{array}$ \\
\hline & $3.12 ; 4.12$ & $\begin{array}{l}\text { Menyajikan dan menafsirkan data dalam bentuk tabel, diagram } \\
\text { garis, diagram batang, dan diagram lingkaran. }\end{array}$ \\
\hline \multirow[t]{7}{*}{ VIII } & $3.1 ; 4.1$ & $\begin{array}{l}\text { Menyelesaikan masalah yang berkaitan dengan pola pada } \\
\text { barisan bilangan dan barisan konfigurasi objek. }\end{array}$ \\
\hline & $3.2 ; 4.2$ & $\begin{array}{l}\text { Menyelesaikan masalah yang berkaitan dengan kedudukan } \\
\text { titik dalam bidang koordinat Kartesius. }\end{array}$ \\
\hline & $3.3 ; 4.3$ & $\begin{array}{l}\text { Menyelesaikan masalah yang berkaitan dengan relasi dan } \\
\text { fungsi dengan menggunakan berbagai representasi. }\end{array}$ \\
\hline & $3.4 ; 4.4$ & $\begin{array}{l}\text { Menyelesaikan masalah kontekstual yang berkaitan dengan } \\
\text { fungsi linear sebagai persamaan garis lurus. }\end{array}$ \\
\hline & $3.5 ; 4.5$ & $\begin{array}{l}\text { Menyelesaikan masalah yang berkaitan dengan sistem } \\
\text { persamaan linear dua variabel. }\end{array}$ \\
\hline & $3.6 ; 4.6$ & $\begin{array}{l}\text { Menyelesaikan masalah yang berkaitan dengan teorema } \\
\text { Pythagoras dan tripel Pythagoras. }\end{array}$ \\
\hline & $3.7 ; 4.7$ & $\begin{array}{l}\text { Menyelesaikan masalah yang berkaitan dengan sudut pusat, } \\
\text { sudut keliling, panjang busur, dan luas juring lingkaran, serta } \\
\text { hubungannya. }\end{array}$ \\
\hline
\end{tabular}




\begin{tabular}{|c|c|c|}
\hline Kelas & $\begin{array}{l}\text { Kompete } \\
\text { nsi Dasar }\end{array}$ & Nama Kegiatan di Mapel Matematika \\
\hline & $3.8 ; 4.8$ & $\begin{array}{l}\text { Menyelesaikan masalah yang berkaitan dengan garis singgung } \\
\text { persekutuan luar dan persekutuan dalam dua lingkaran. }\end{array}$ \\
\hline & $3.9 ; 4.9$ & $\begin{array}{l}\text { Menyelesaikan masalah yang berkaitan dengan luas permukaan } \\
\text { dan volume bangun ruang sisi datar (kubus, balok, prima dan } \\
\text { limas), serta gabungannya. }\end{array}$ \\
\hline & $3.10 ; 4.10$ & $\begin{array}{l}\text { Menyajikan dan menyelesaikan masalah yang berkaitan } \\
\text { dengan distribusi data, nilai rata-rata, median, modus, dan } \\
\text { sebaran data untuk mengambil kesimpulan, membuat } \\
\text { keputusan, dan membuat prediksi. }\end{array}$ \\
\hline & $3.11 ; 4.11$ & $\begin{array}{l}\text { Menyelesaikan masalah yang berkaitan dengan peluang empirik } \\
\text { dan teoretik suatu kejadian dari suatu percobaan. }\end{array}$ \\
\hline \multirow[t]{7}{*}{ IX } & $3.1 ; 4.1$ & $\begin{array}{l}\text { Menyelesaikan masalah yang berkaitan dengan sifat-sifat operasi } \\
\text { bilangan berpangkat bulat dan bentuk akar. }\end{array}$ \\
\hline & $3.2 ; 4.2$ & $\begin{array}{l}\text { Menyelesaikan masalah yang berkaitan dengan persamaan } \\
\text { kuadrat. }\end{array}$ \\
\hline & $3.3 ; 4.3$ & $\begin{array}{l}\text { Menyajikan fungsi kuadrat menggunakan tabel, persamaan, } \\
\text { dan grafik. }\end{array}$ \\
\hline & $3.4 ; 4.4$ & $\begin{array}{l}\text { Menyajikan dan menyelesaikan masalah kontekstual dengan } \\
\text { menggunakan sifat-sifat fungsi kuadrat. }\end{array}$ \\
\hline & $3.5 ; 4.5$ & $\begin{array}{l}\text { Menyelesaikan masalah kontekstual yang berkaitan dengan } \\
\text { transformasi geometri (refleksi, translasi, rotasi, dan dilatasi). }\end{array}$ \\
\hline & $3.6 ; 4.6$ & $\begin{array}{l}\text { Menyelesaikan masalah yang berkaitan dengan kesebangunan } \\
\text { dan kekongruenan antar bangun datar. }\end{array}$ \\
\hline & $3.7 ; 4.7$ & $\begin{array}{l}\text { Menyelesaikan masalah kontekstual yang berkaitan dengan luas } \\
\text { permukaan dan volume bangun ruang sisi lengkung (tabung, } \\
\text { kerucut, dan bola), serta gabungan beberapa bangun ruang sisi } \\
\text { lengkung. }\end{array}$ \\
\hline
\end{tabular}

D. Daftar Mata Praktikum Maya Matematikan di Aplikasi PhET

\begin{tabular}{|c|l|c|l|}
\hline No & \multicolumn{1}{|c|}{ Judul Praktikum } & Kelas/ Sem & \multicolumn{1}{c|}{ Ket } \\
\hline 1 & Pendahuluan Pecahan & VII/1 & Java \\
\hline 2 & Membuat Pecahan & VII/1 & Java \\
\hline 3 & Persamaan Pecahan & VII/1 & HTML version \\
\hline 4 & Persamaan Pecahan Campuran & VII/1 & HTML version \\
\hline 5 & Model Desimal & VII/1 & HTML version \\
\hline 6 & Pecahan Senilai dan Pecahan Campuran & VII/1 & Java \\
\hline 7 & Garis Bilangan: Bilangan Bulat & VII/1 & HTML version \\
\hline 8 & Model Aljabar & VII/1 & HTML version \\
\hline 9 & Persamaan Linier (Dasar) & VII/1 & HTML version \\
\hline 10 & Persamaan Linier 1 Variabel & VII/1 & HTML version \\
\hline 11 & Rasio & VII/2 & HTML version \\
\hline 12 & Proporsi & VII/2 & HTML version \\
\hline 13 & Aritmatika & VII/2 & $\begin{array}{l}\text { Flash/HTML } \\
\text { version }\end{array}$ \\
\hline 14 & Menggambar Garis & VIII/1 & Java \\
\hline
\end{tabular}




\begin{tabular}{|c|l|c|l|}
\hline No & \multicolumn{1}{|c|}{ Judul Praktikum } & Kelas/ Sem & \multicolumn{1}{c|}{ Ket } \\
\hline 15 & Grafik Persamaan & VIII/1 & $\begin{array}{l}\text { Flash/HTML } \\
\text { version }\end{array}$ \\
\hline 16 & Membuat Fungsi & VIII/1 & HTML version \\
\hline 17 & Membuat Fungsi (Dasar) & VIII/1 & HTML version \\
\hline 18 & Grafik Fungsi Linier & VIII/1 & HTML version \\
\hline 19 & Gradien & VIII/1 & HTML version \\
\hline 20 & Persamaan Linier 2 Variabel & VIII/1 & HTML version \\
\hline 21 & Statistika Peluang & VIII/2 & HTML version \\
\hline 22 & Estimasi & VIII/2 & HTML version \\
\hline 23 & Grafik Fungsi Kuadrat & IX/1 & HTML version \\
\hline
\end{tabular}




\section{DAFTAR PUSTAKA}

Kemendikbud, 2017. Kurikulum 2013 Edisi Revisi: Standar Kompetensi dan Komeptensi Dasar IPA dan Matematika SMP.

https://phet.colorado.edu/in/

https://java.com/en/download/ 


\section{BIODATA PENULIS}

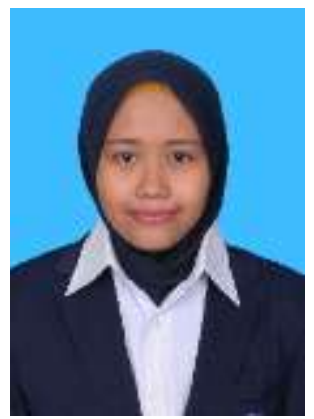

Dr. Septi Budi Sartika, S.Pd., M.Pd. lahir di Ponorogo, 9 September 1985. Lulus Sarjana Pendidikan Fisika Universitas Negeri Surabaya tahun 2008, melanjutkan studi S2 di Prodi Pendidikan Sains Program Pascasarjana Universitas Negeri Surabaya lulus tahun 2010. Lulus program Doktor di prodi Pendidikan Sains Program Pascasarjana Universitas Negeri Surabaya tahun 2019. Karir pengajaran dimulai tahun 2010 di Fakultas Keguruan dan Ilmu Pendidikan Universitas Muhammadiyah Sidoarjo. Penulis terlibat dalam penelitian dan pengabdian kepada masyarakat baik didanai oleh Ristekdikti maupun dana mandiri tentang keterampilan berpikir tingkat tinggi dan keterampilan Abad-21.

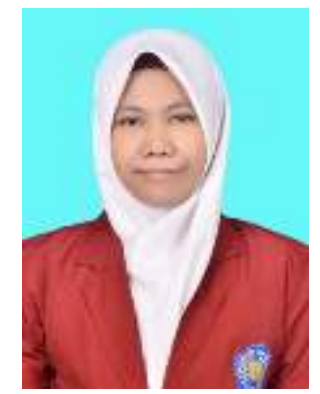

Eni Setiyoningrum, S.Pd. lahir di Magetan, 25 Februari 1996. Penulis adalah anak ke empat dari empat bersaudara. berasal dari Ds. Karangmojo RT. 15 RW. 04 Kecamatan Kartoharjo Kabupaaten Magetan. Lulusan S-1 Pendidikan IPA di Universitas Muhammadiyah Sidoarjo tahun 2019. Karir bekerja dimulai dari tahun 2014 sampai dengan 2019 sebagai admin gudang di CV. Karya Persada Sidoarjo. Tahun 2019 sampai sekarang bekerja di SMP Wachid Hasjim 9 Sedati yang saat ini menjabat sebagai guru IPA, Wali Kelas, dan Kepala Laboratorium IPA. 
ISBN 978-623-6833-03-2

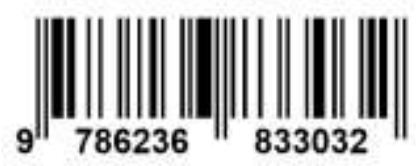

